\title{
المعجمُ العربي " بين الاقتصاد والإفراط
}

م.د علي حلو حواس/جامعة بغداد/ كلية التربية ابن رشد

م.د علي حسن /جامعة واسط /كلية التربية / قسم اللغة العربية

مُقدّمة

القصد لغنةً استقامة الطريق،وقوله تعالى : (( وعلى اللهِ قَصَدُ السَّبيلِ )) (') ،أبي على اللهِ تبيينُ

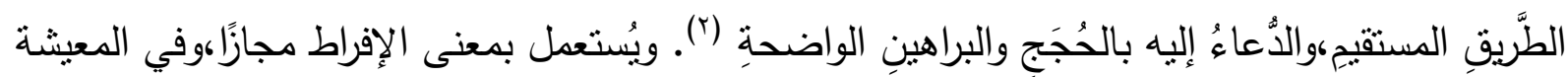

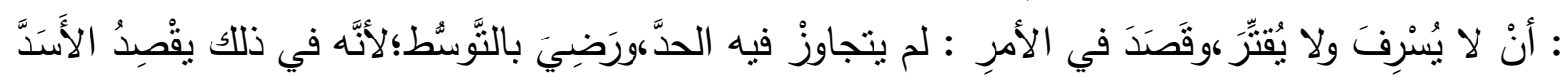

وتميل الموجودات الكونيَّة إلى الاستقامة والاعتدال،فتحاول جاهدةً أنْ تصل إلى مرحلـة أكثر

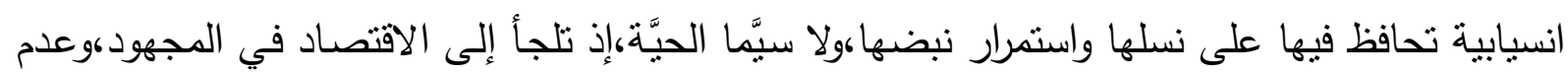

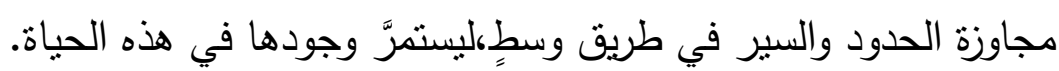

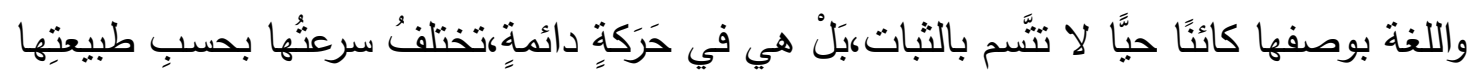

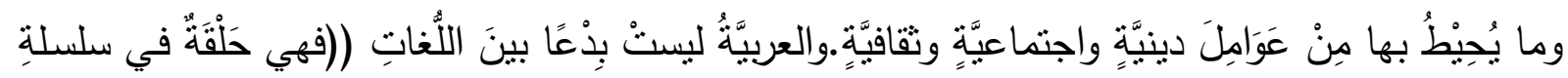

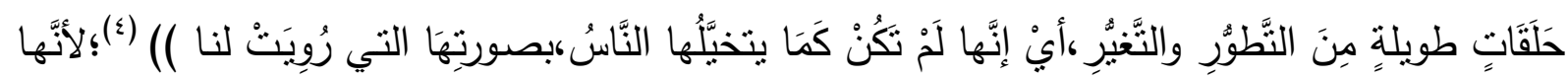
لا تعيشُ وحذَها.

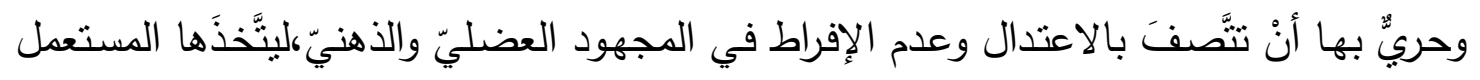

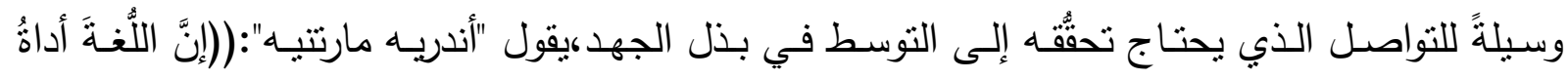

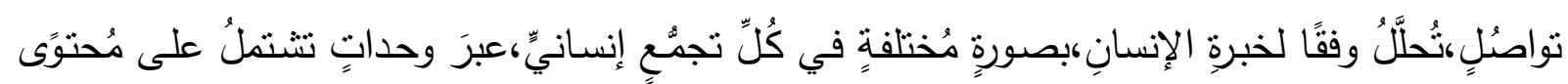

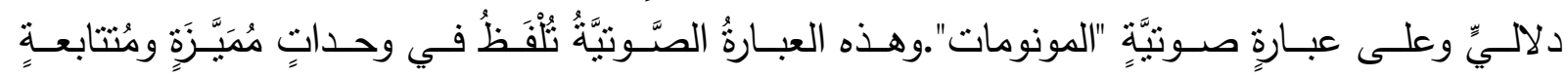

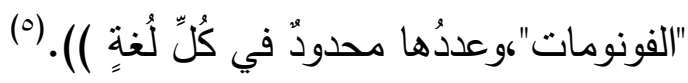

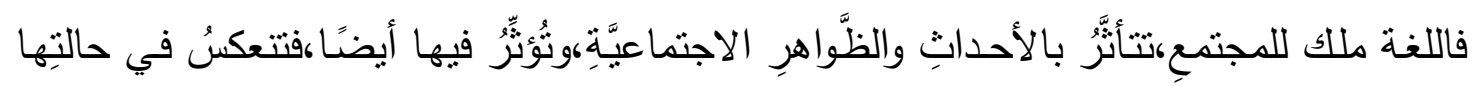

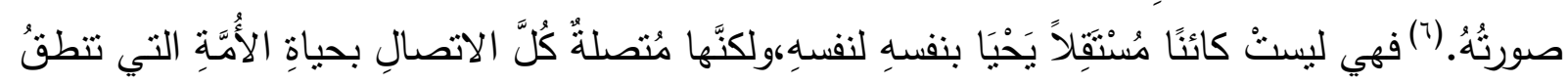

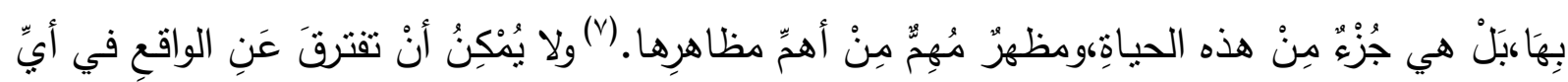

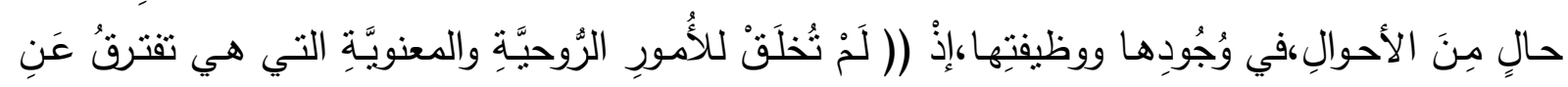

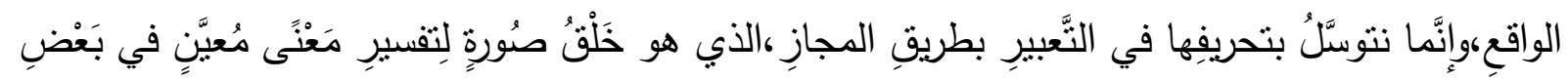

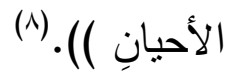


ويبدو أنَّ مصطلح "الاقتصـاد" يدلُّ على المبالغـة في الاستقامة،فهو مصدر الفعل "|قتصد"،قال

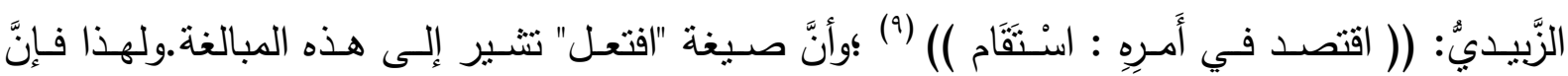

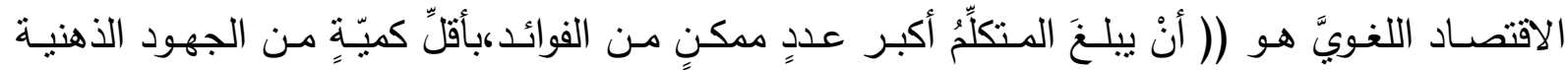

والعلاجية لآلة الخطاب () (·).')

والاقتصـاد في اصطلاح اللسانيِّن هو أنْ يكون المعنى المندرج تحت عبارة حسب ما يقتضيه

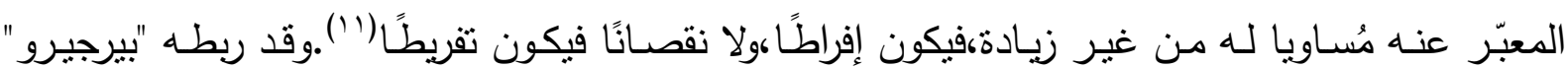
بشرط الجهذ الأقل ولهذا فهو يُعُُّ مصدرًا آخر من مصادر تغيُّر المعنى (r').

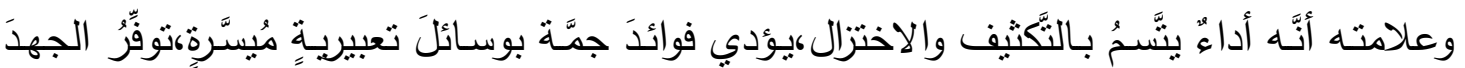

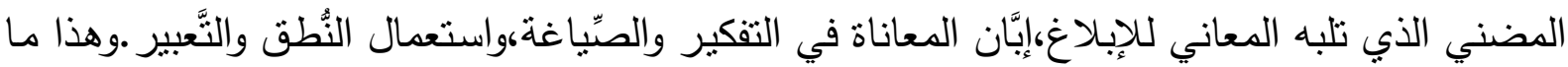
يُعبَّر عنه أحيانًا بقانون الجُهد الأدنى (r')، أو قانون التيسير والسهولة في مستويات اللُّنة كافة،الصوتيّ والصرفيّ والتركيبيّ والدّلاليّ. وقد أثنـار بعض البـاحثين إلى أنَّ الاقتصـاد هـو أنْ تعبِّرَ بالقليـل المتــاهي عن الكثيـر غيـر

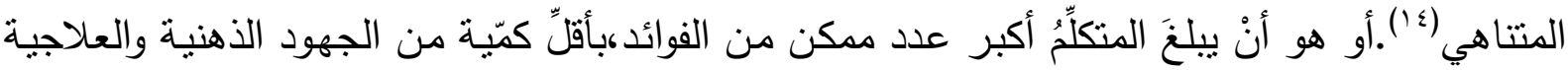
لآلة الخطاب(10). ولا تقتصـر هذه الظاهرة على اللغـة العربيَّة فحسب وبوانَّما هـي ظـاهرة معروفـة في لغـات العـالم

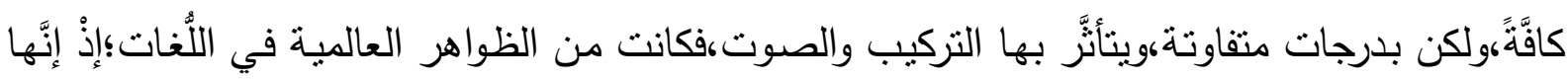
ليست وقفًا على لغةٍ دون أخرى(1').

العربيَّة لغةٌُ اقتصاديَّةُ لو قرأنا اللغنةَ العربيَّةَ قراءةً لسانيَّةً بمستوباتها الصونيَّة والصرفيَّة والتركيبيَّة والدّلاليَّة لوجدنا سمة التكثيف والاختزال والاقتصاد في المجهودين العضلي والفكري واضحةً وجليَّةَوهي ليست بِذِعًا من اللغات

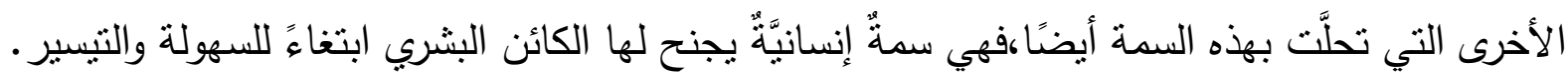
وما دامت اللُّغات في تطوُّرٍ مستمرٍٍ لا يوقفها شيءُ،فإنَّ الملامح الاقتصادية ترافقها في كلّ زمان ومكانٍ،وهي في العربيَّة أجلى وأظهر ،وهي ظاهرة أصيلة فيها.(( فقد وردت في القرآن الكريم كما وردت في شواهد النحاة والبلاغيّين،فالنحويُّ ينظر إليها من ناحيبة هل يجوز حذف كلمة مقابل وجود علامـة إعرابيَّة نتوب عن ذلك ؟ إذ جوَّزوا حذف الفعل والفاعل والمفهوم وغيرهم.أمَّا البلاغيُّون فينظرون إلى هي

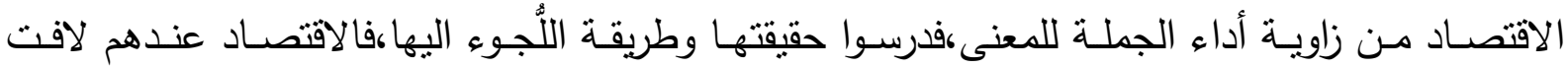
للانتباهوله أغراض بلاغيَّة واضحة تظهر بوضوح في سمات الاقتصاد .أمَّا علماء الأصوات فينظرون إلى 
هذه الظاهرة من خلال خدمتها لأصـواتهمهوكيف يمكنها أنْ تؤدي المعنى بوجودها.وكذللك الدّلاليُّون فهم

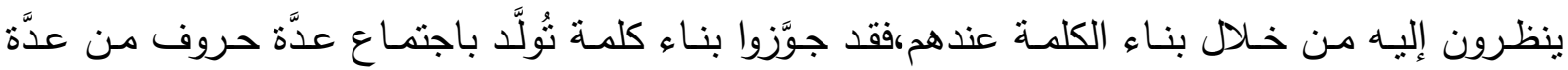

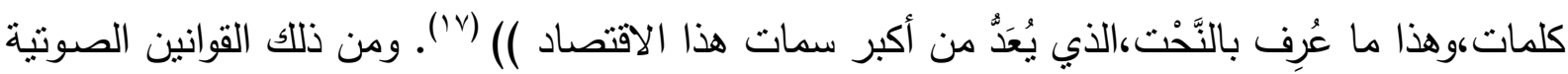
مـن مشـاكلة وممانلـة ومجانسـة وغيرهـا،والقوانين الصـرفيَّة مسن إعـلال وإبـدال وحذف ونقل، ومـا يتعلق بالأنظمـة التركيبيَّة مـن اختزال وتخلٍِ عن كثبر من التراكيب اللهجيـة المعروفة والاقتصـار على اللغـة

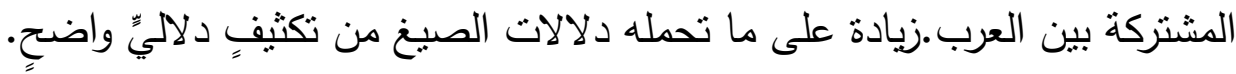
وسنكرّس بحثنا هذا على مدى إفادة المشتغلين في التأليف المعجميّ من هذه السمة التي عرفتها

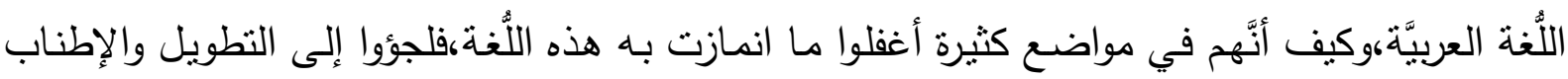
غير المسوَّغ في ايراد الألفاظ ودلالاتها،وحرصوا على إيراد النصوص المتعلِّة بدلالات الجذر اللُّغوي كافَّة،وإنِ اتفقت في المضمون،مِمَّا أنقل المعجم العربي بمادَّة كثيرة كان الأحرى بهم أنْ يقتصدوا وبعتدلوا

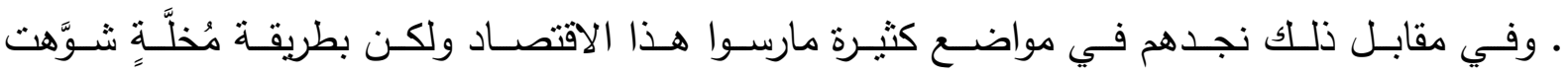

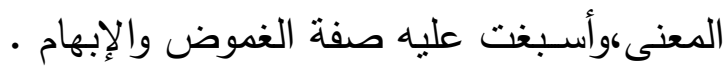

مالمح اقتصاديَّة

لو قرأنا في أول معجمٍ عربيٍٍ ظهر للوجود وهو العين للخليل بن أحمد الفراهيديّ ( ت م ا هـ ) لوجدنا ملمحًا اقتصـاديَّا واضـحًا،وهو إهمالـه للتفريعـات المعقدة للجذر اللغويٍّ التي هـي نتيجـة للتقسيم الرياضـي الذي اتبعـه في حصـر كـلام العرب،إذ أهمل مـا أهملـــه العربيٌُ ليحصـر نشـاطه في زوايـا

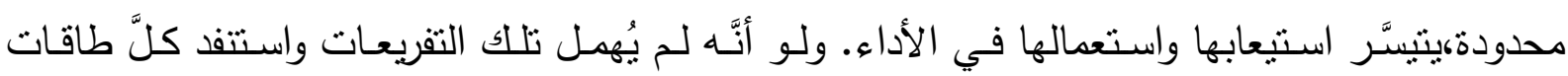
لُغته،بتوليـد المفردات التي تحتملهـا القسـة الرياضـية،لكان لـدينا مـن الكلمـات للاسـم المجـرد الثلاثي

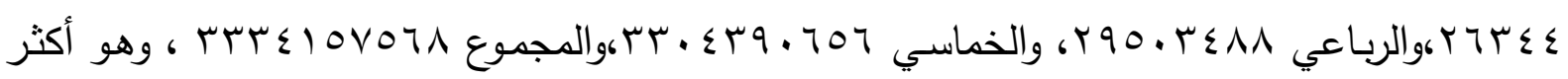

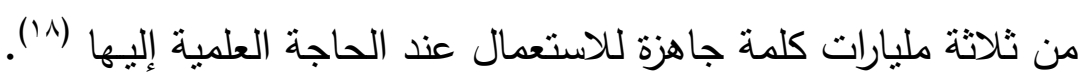
ويشخص في معجم العين ملهُح اقتصـاديٌّ آخر كيبدو أنَّ الخليل أوَّل من استعمله،وهو الاعتماد على الأبواب في تقسيم المادة اللغوبة،فضـاً عن نظام التقليبات آنف الذكر ،وهي عنده خمسـة : الثتائي المضاعف، والثلاثي الصحيح، والثلاثي المعتل، واللفيف - أي المعتل بحرفين - وأخيرا أبواب الرباعي

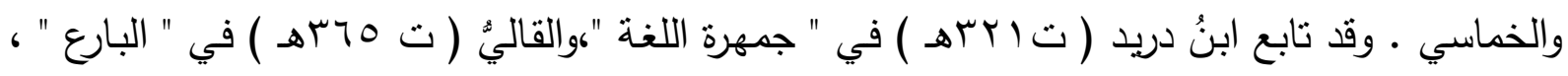

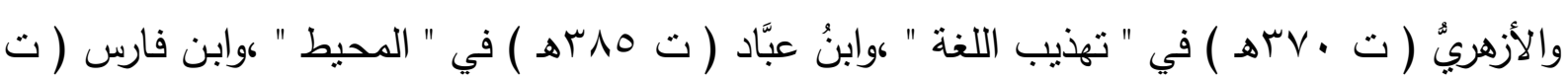

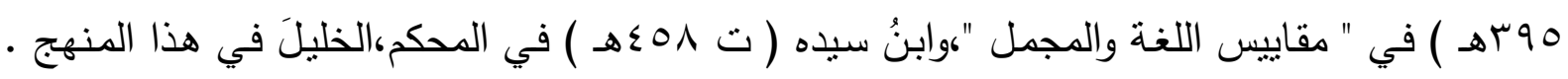
وقد استوعبت هذه الأبواب جميع الأبنية العربيَّة وأضفت عليها سمةً اقتصاديَّة. 
ومن مصاديق الاقتصاد اللغويٍ الأخرى منهج التبئير الدّلاليّ الذي ابتدعه ابن فارس ( ت هوبه

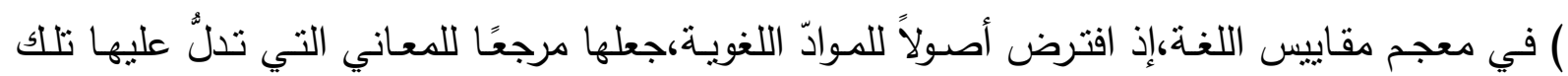
الأصول،فأصبح بحق أنموذجًا للتكثيف الدّلاليّ والاقتصساد في الجهد الذّهني المبذول. ولم يُعرف هذا المنهج قبل ابن فارس؛إذ أحدث نقلةً نوعيَّةً في التأليف المعجميّ،فهو لم يقتصر على الجمع والتفسير مثلما فعل السابقون،بل حاول أيضا أن يكثف الستار عن المعنى الأصليّ للمادّةثثم يورد تحته الألفاظ التي تحمل ملامح ذلك المعنى،وسمَّى نلاك المعاني (الأصول والمقاييس). وهذه نظريَّة تحليليَّة تركيبيَّة للقدرة المعجميَّة على الاقتصاد،بالتكثيف للمعاني في بُؤَّر متقاربةٍة أو مُوحَّدةٍهواستبعاد كثيرٍ من التفريعات اللفظيَّة؛استغناء عنها بذللك التكثيف.(( ولو استخلَّ المعاصرون هذه النظريَّة الفذَّة لاستطاعوا أنْ يُولِّدوا ألفاظًا من تلك البُؤَر المعنويَّة المحدَّدة للمخترعات والمُستجدات في عالم الأشياء والأفعال والمواصفات،دون الاستجداء للرَّطانات الأعجميَّة والمصطلحات الأوروبيَّة،والتراكيب

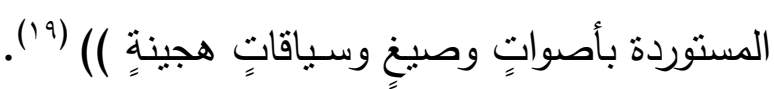
إلاّ أنَّ تلك الفكرة لم تتطبق على الألفاظ الرُّباعية والخماسيةهوإنَّما اقتصر تطبيقها على الألفاظ

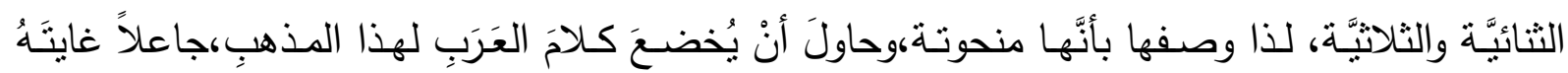

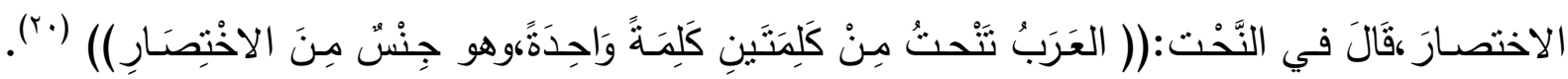

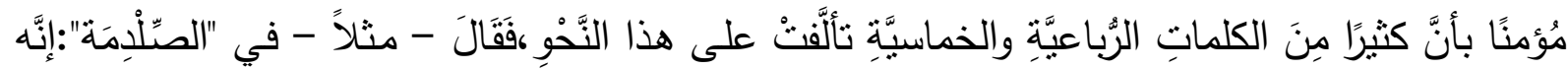

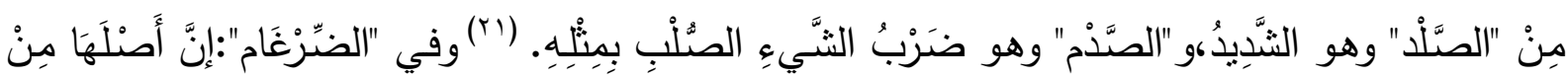

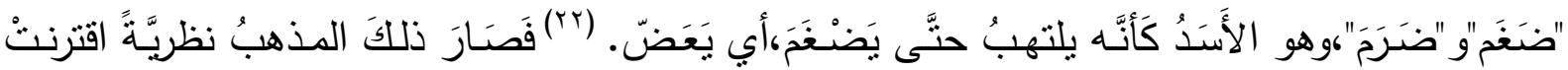

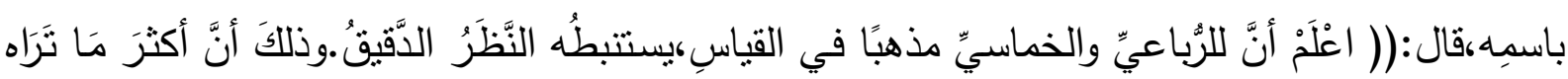

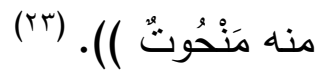

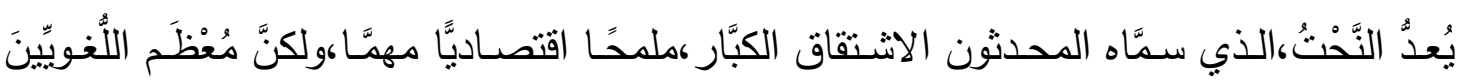

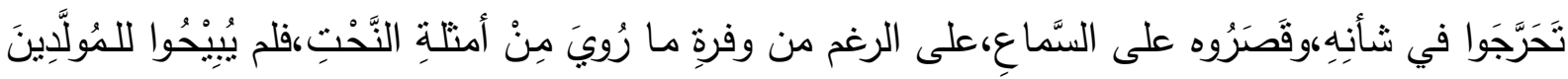

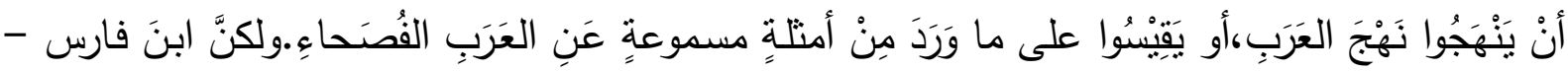
كما رأينا آنفًا - عدَّه قياسيَّا.

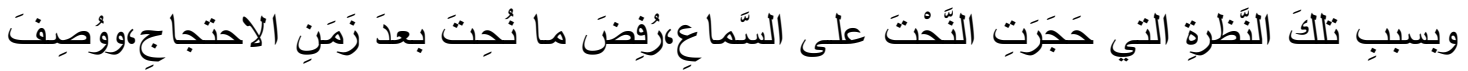

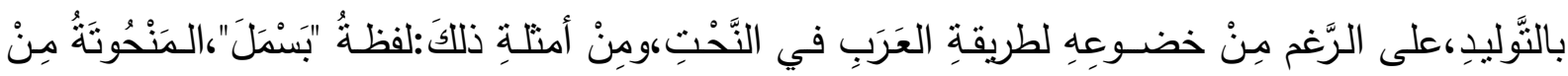

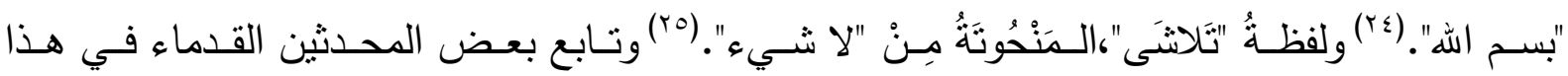

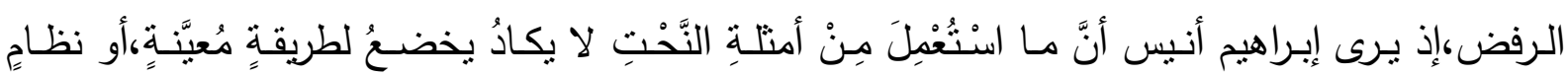

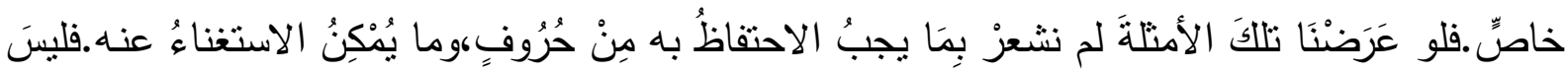




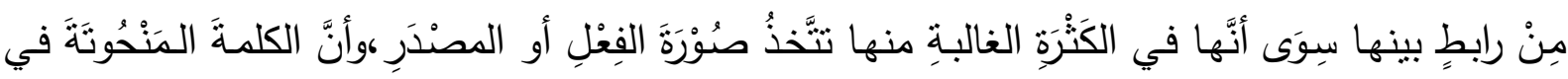

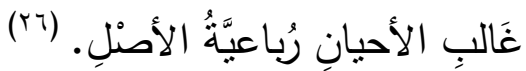

في حين يَرَى آخرون أنَّ القُدَماءَ استتدوا إلِى مَنْهَجِ مُحدَّدِفقِدِ اسْتَخْرَجَ رمسيس جرجس - بعدَ

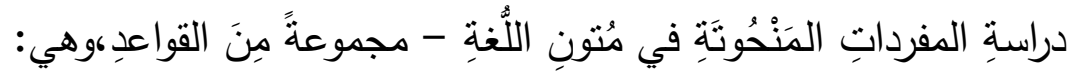

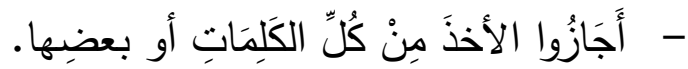

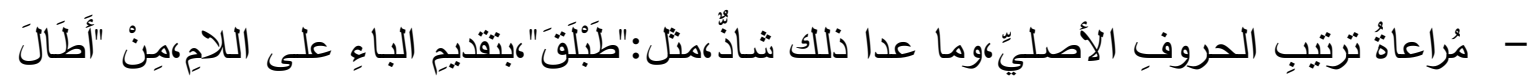

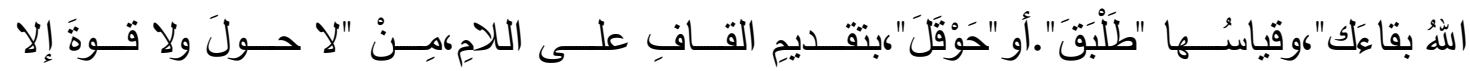

$$
\text { بالهَ"،وقياسُها "حَوْلَقَ". }
$$

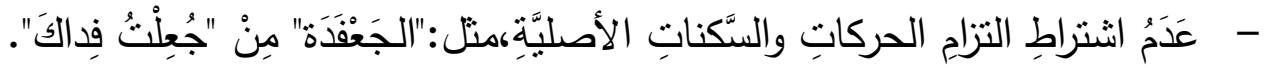

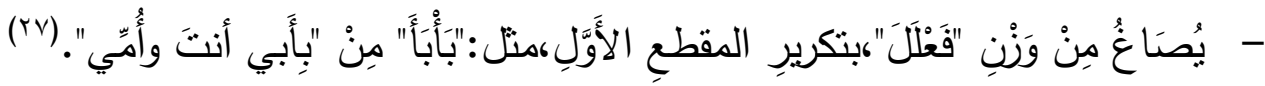

وبغضِّ النظر عمَّا قيل بشأن النَّحْت،فهو وسيلة مهمة من وسائل الاقتصاد اللغويّ والاعتدال في الجهد المبذول،وميدان ذلك هو تقليل المباني ودفع الإطالة بإقامة تعبير قصير مقام آخر طويل،فبدلا من

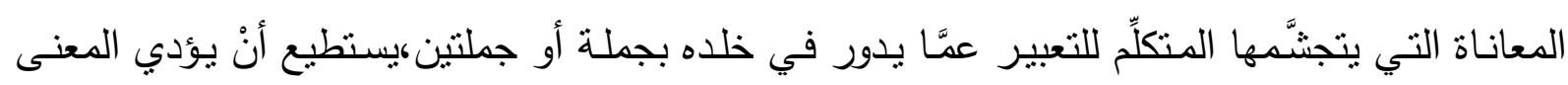
نفسه بكلمة منحوتة،فضلاً عن كونه وسيلةً مهمَّةً في تتمية اللُّة ورفدها بالمصطلحات الجديدة. ومسن مصـاديق الاقتصـاد الأخرى ظـاهرة الاثتقاق،التي اختلفت مدلولاتها بحسب الميدان الذي

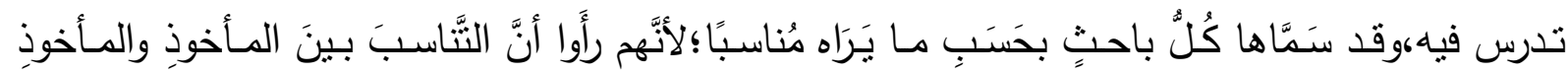

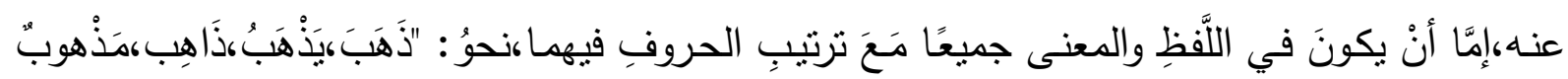

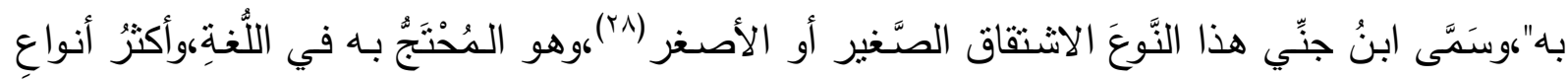
الانشتقاق استعمالاً واتِّاعًا.

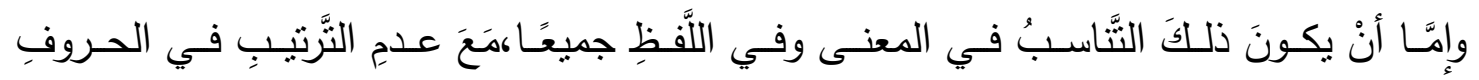

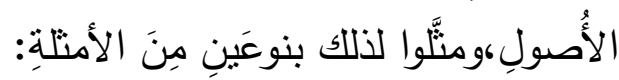

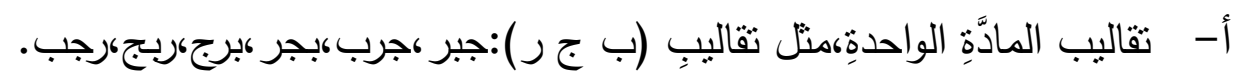

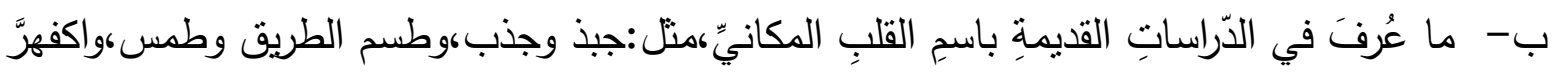
الجوٌٌ واكْرَهَفَّن.

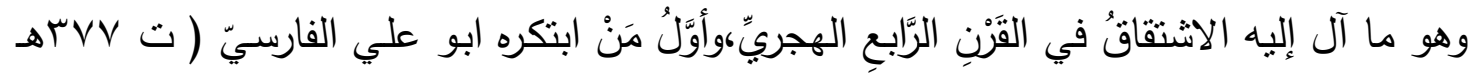

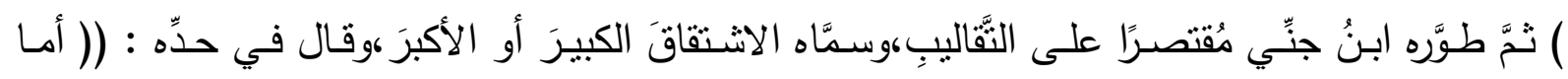

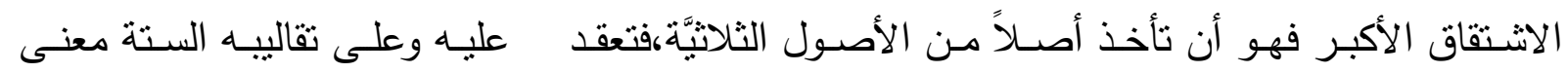


واحداً،تجتمع التراكيب الستة وما يتصرف من كل واحد منها عليه،وإن تباعد شيء من ذلك عنه ردّ بلطف

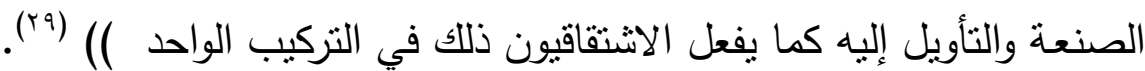
وهو ملهـح اقتصـاديٌّ واضـح يحفل بتكثيف المعاني المتقاربة في تقليبات الجذر اللغويّ،فتقليبات الجـذر اللغـويّ " ق س و " تحـوم حـول معنـى القـوة والاجتماع،ومنهــا : القسـوة : وهـي شـدَّة القلـب

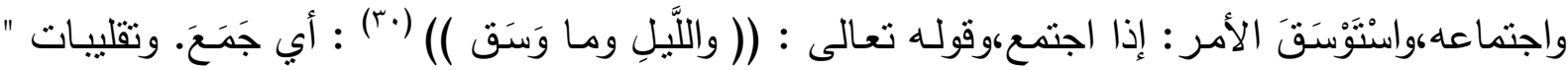

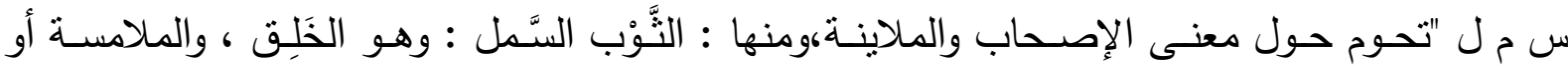
لامستم النساء : أي جامعتم ،وغير ذلك (بام). ويبدو أنَّ هذه الظاهرة تحمل طاقاتٍ إنجابيَّةً واسعةًُ،هي تمدُّا بألفاظٍ وافرة،تُصـاغ من مهملات بعض التقليبات،للاّلالة على المعاني المستجدَّة،إذا كانت قريبةً مِمَّا يدور في التقليبات المُستعملة،والأحرى

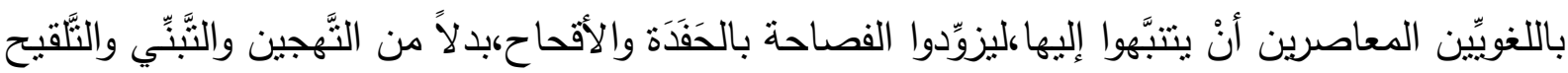
الاصطناعي والاستساخ الأعجميّ (r؟r).

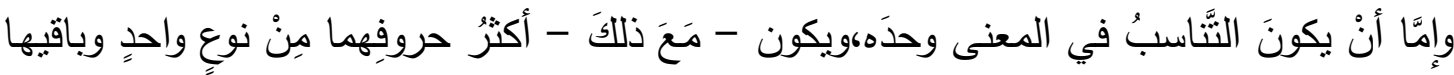

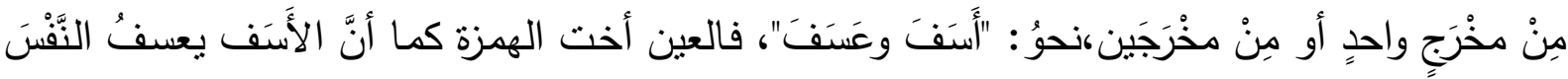
وينالُ منها ، والههزة أقوى من العين كما أنَّ أسف النفس أغلظ من التَّردد بالعسف. و "قَََََ و قَرَمَ" ، فالقرمة وهي الفقرة تحز على أنـف البعير .وقريـب منـه قلمـت أظفـاري لأن هذا انتقاص للظفر وذلك انتقاص للجلد.فالراء أخت اللام والعمـلان متقاربان. واستعملوا تركيب "ج ب ل "و " ج ب ن "و " ج ب ر "

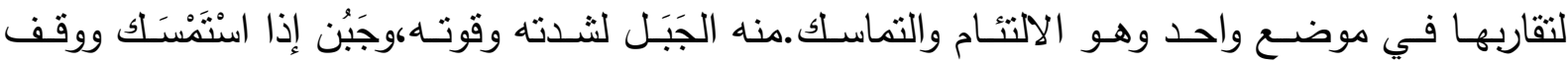

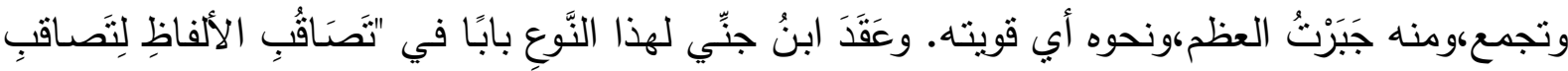

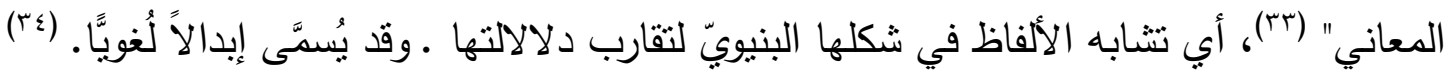

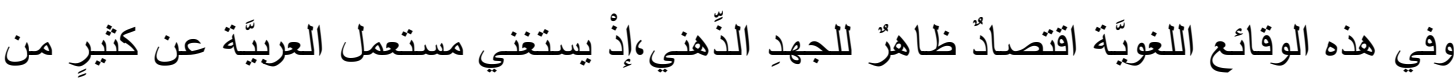
الموادِّ الجديدة البعيدة عن مألوفه،وييقى في أحيازٍ مُتداوَلة مُيسَّرةٍ يستوعبها مِمَّا تحتمله التَّراكيب في ضمِّ الحروف بعضها إلى بعضٍ،لتبقى تلك المهمات رصيدًا احتياطيَّا،ينتظر ما يناسبه من المقاصد الجديدة البعيدة عن المـألوف فيُستَعمل حينذاك.فيتحقَّق التيسير بسدِّ ما تحتاجه الأجيال من صياغات،تسـتوعب الجديد من المعاني والأشياء في تاريخ العلوم والتجارب.(( ولكنَّ هذه الأجيال المقصود عونها وتوجيهها

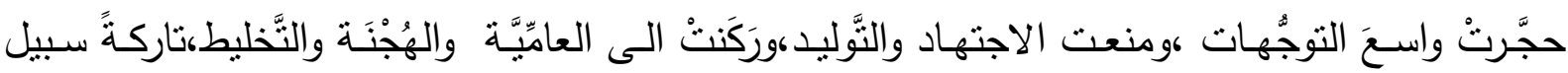
القصد والاعتدال () (ro) (1)

ويمكن القول باطمئنان إنَّ مظاهر الاقتصاد اللُّنيّ في المعجم العربيّ كثيرة لا يحدُّها حصرٌ ،فإذا نظرنا في الآلية التي اعتمد عليها المعجميٌ في ضبط الألفاظ،وجدنا أنَّه اعتمد بادئ الأمر على الضبط بالقلم،وهو أوَّل أسلوب اعتمدت عليه المعجمات المتقدمة، ولاسيَّما كتاب العين،إذ استتد صـاحبه إلى ما 


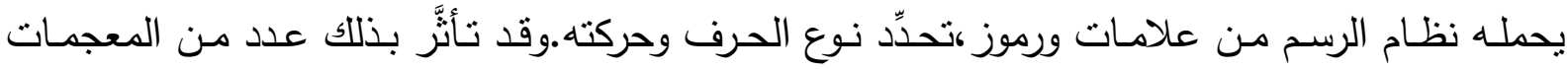
الحديثة،كمعجم (متن اللغـة) لاحمد رضـا العاملي،و (محيط المحيط) لبطرس البستاني،ولعلها لجأت إلى مئ ذللك أملاً في تحقيق الإيجاز والاختصار واعتقادا منها أنَّ السُُّّل الأخرى نشغل حيّزًا كبيرًا من المعجم. وقد ظلَّت الكتابـة العربيَّة معرَّضـة للخطأ والتغبير ،ولا سيَّما مع تقادم الأزمان؛ لأنَّها لا تبين نطق الحروف التي ترسمها،وتحتاج إلى وسـائل أخرى لضبط أنواع الحروف وحركاتها. ثَُُّّ انَّ اللُّنـة المكتوبـة تختلف عن المنطوقة، من حيث نسبة الغموض الذي يكتنفها؛ إذْ إنَّها - أبي المكتوبة - تحصر الكلام في

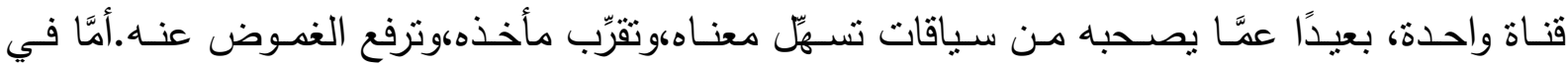

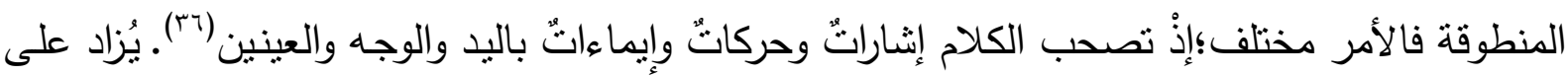
ذلك أنَّ نظام الكتابة في أي لغة لا يعكس بدقَّة نظام النطق لهذه اللُّة؛؛لأنَّ الكتابة بطبيعتها من حيث هي

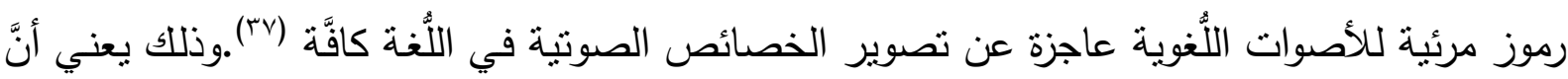
نظام الرسم لا يتطابق مع النُّطق بالضرورة،ولاسيَّما حين ثُراعَى اعتبارات أخرى بعضها تأريخيٌٌ وبعضها

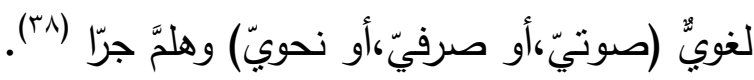
وقد جعل حمزة بن الحسن الأصفهانيّ(· . بس هـ) قصور نظام الرسم سبيًا في حدوث التَّصحيف في اللُّنة العربيَّة، إذْ قال: ((إنَّ الذي أبدع صسور حروفها لم يضـعها على حكمة،ولا احتاط لمن يجيء

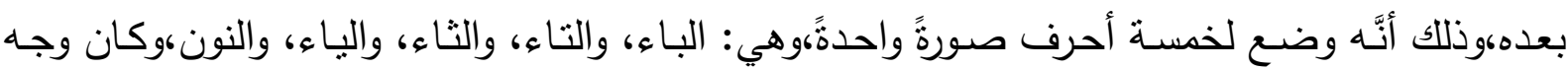
الحكمة فيه أنْ يضع لكل حرف صورةً مباينةً للاخرى؛حنَّى يؤمن عليه التبديل)( (ra). وقد أحدث هذا الأسلوب تصحيفًا كثيرًا في المعجمات؛لأن الرموز والعلامات قد تختفي مع الزمن، ئن أو يغيَّر موضـعها الصحيح؛بسـبب السـرعة،أو جهـل الناسـخ، أو إهمالـه فضــلاً عـن كثـرة الاستتسـاخ

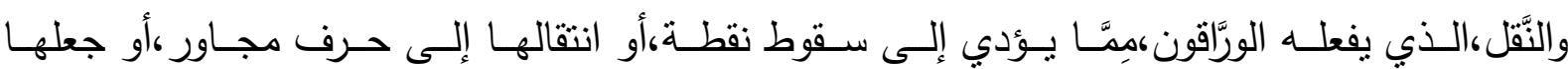
نقطتين...وغير ذلك. ويترتَّب على ذلك نطق كلمـة جديدة قد نكون صـحيحة لغـة ومعنى،ولكنَّها غير الكلمة التي قصدها واضعها الأول (·ء). وقد لا يكون لها معنى على الاطلاق.وقد يؤدي النَّصحيف أيضًا إلى تغيير حركة الحرف،فيترتَّب عليه نشوء أمتلة جديدة،تدرج تحت صيغ صرفيَّة مخالفة لما كانت عليه قبلاً،وقد تخرج عن صيخ الصرف ومقتضيات اللفظ أصلاً فيحكم عليها بالخطأ.والاول من هذين النوعين: انحراف في المعنى .والثاني: انحرافُ لغويٌٌ في بنية الكلمات( (؛). فالضـبط بـالقلم _ـ وإنْ كان مظهرًا اقتصـاديًّا - فإنَّهـ لا يحقق الغايـة المنشـودة مـن وراء الضـبط والمتمثلة بالمحافظة على الكلمة العربية من النَّصحيف والتَّحريف.

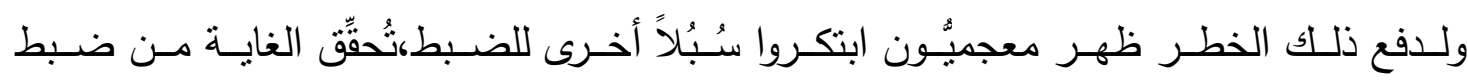
الكلمة،وتجعلها في مأمن من النَّصحيف والتَّحريف،وإنْ كانت لا تحقِّق اقتصادًا في الجهد المبذول.ومن

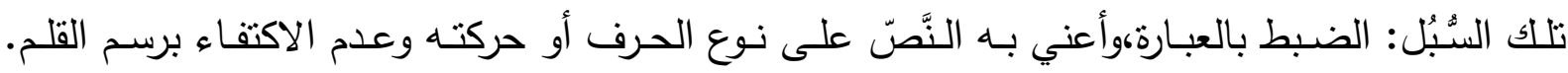


والضبط بالميزان،وهو على قسمين،أحدهما: النَّصّ على وزن الكلمـة الصرفيّ مباشرة،باستعمال الموازين الصرفيَّة. والآخر : النَّصُّ على وزن الكلمة بكلمة أخرى أشنهر وهو ما يسمَّى (الضبط بالتمثنل). ولا تخلو هذه السُُبّل في الضبط من الاقتصاد اللغويّ؛فنجد عددًا من المعجميِين يستعلمون لفظة واحدة تؤدي معنى جملة أو عبارة،ومن أمثلة ذلك قولهم: "بالتتليث" أو "مثلَّثة"،وتكون مع الأسماء لضبط الحرف الأول،ومهع الأفعال لضبط الحرف الثاني.ويُعَدُّ الفيروزابادي من أكثر المعجميِينين الذين استعملوا

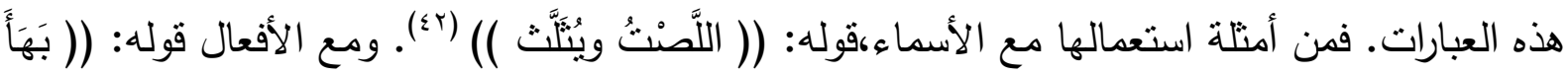

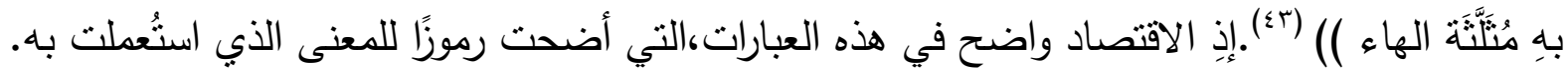

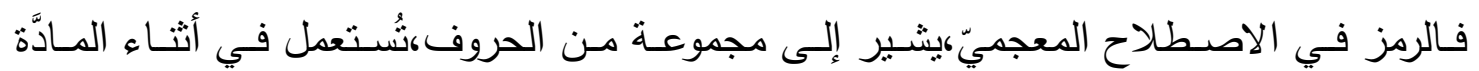
المعجميَّة،بغية الضبط او التقسير،في سبيل تحقيق الاختصـار ،الذي افتقرت إليه المعجمات الأولى،حتى جاء الفيروزابادي،فجعل قاموسه منفردًا بتلك الرموز، التي جسَّدها بأحرف خسمة،نظمها هو في قوله:

$$
\text { فميٌْ لمعروفٍ وعينٌ لمَوْضِّع }
$$

وما فيه مِنْ رَزْزِ فخمسةُ أَحْرُف

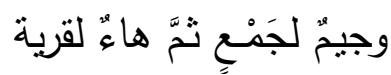

$$
\text { إثـارة واوي ويائيها اسمع }
$$$$
\text { وزاد على ذلك بعضهم: }
$$$$
\text { وفي آخرِ الأبوابِ واوٌ وياؤها }
$$

وقد أضاف أبو نصر الهيرويني رمزين آخرين لم يُشر إليهما الفيروزابادي في مقدمة كتابه.وهما

الرمز بالجيمين إثشارة لجمع الجمع،او بثلاث لجمع جمع الجمع (ء). فمن أمتلة تلك الرموز أنَّ الفيروزآبادي لا يذكر المؤنث مرةً ثانية بعد ذكر المذكر ،بل يقول: وهي بهاء،أي أنثى هذا المذكر بهاء،أي تؤنث بلحاق تاء التأنيث على القياس،نحو : كريم وكربمة.

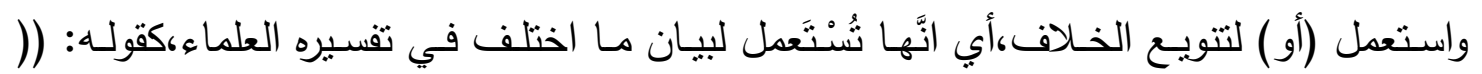

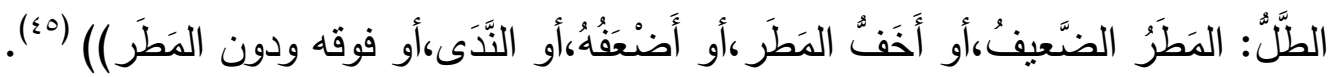
واستعمل (الواو) لتتويع المعنى وتعدُّدهأي انَّها تُشْنَعْمل للاشتارة إلى أنَّ الكلمة المُرَاد تفسيرها لها

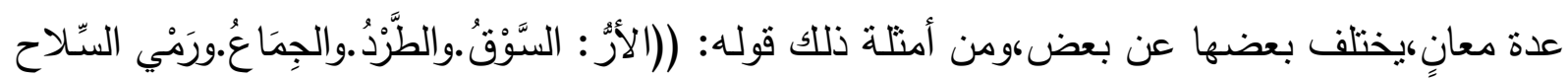

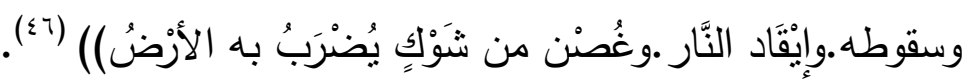
وبتلك الرموز استطاع الفيروزأبادي أنْ يزيد على البناء المعجميّ ظاهرةً منهجيَّةً جديدةً، عُدَّ فيها رائدًا لم يسبق إلبها من قبل،وقد تأثَّر به من لحقه،ولاسيَّما المحدثين بغية الاختصار ،ومحاولة منهم لتهذيب المعجم القديم،وتعويض ما يمكن تعويضه. وقد ابتكر هـؤلاء المحدثون رمسوزًا معجميَّة مزيدة على مـا استعمله الفيروزابادي،فقد اسـتعمل

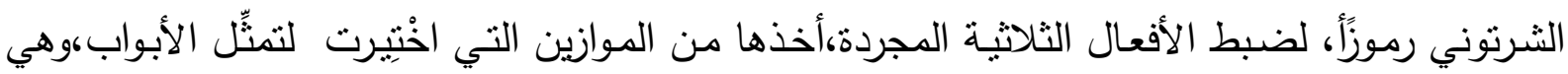


الآتي: البـاب الاول رمـز لـه بحـرف النون،والثـاني بحـرف الضـاد،والثالث بحرف العين،والرابـع بحرف

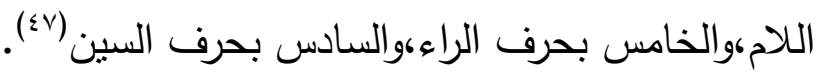

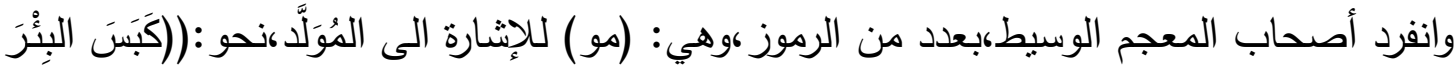

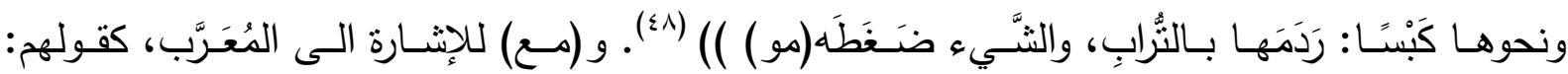

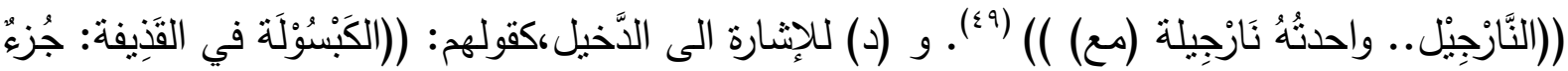

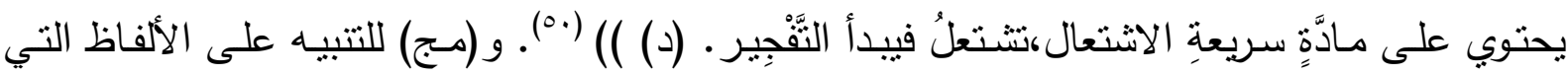

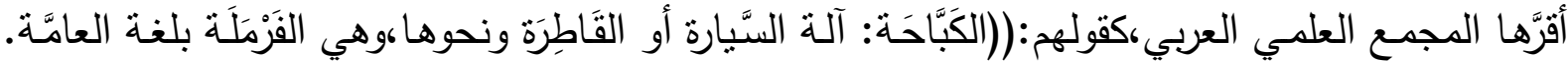

ويمكننا أنْ ندرج تعدُّد المعنى الوظيفي للمبنى في المعجم العربيّ ملمحًا آخر من ملامح الاقتصاد

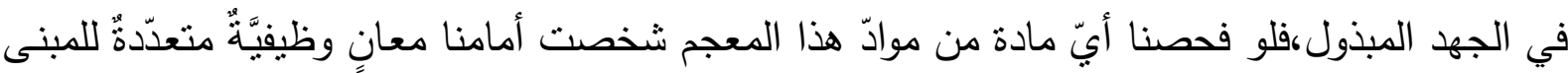
الواحد،بتعدُّد السياق الوظيفي الذي يرد فيه هذا البناء،إذْ (( إنَّ صيغة الكلمة التي يمكن أنْ تدخل في عدد من التبديلات الصيغية سوف يكون لها أيضا امكانات دلاليَّة غنيَّة () (ro).

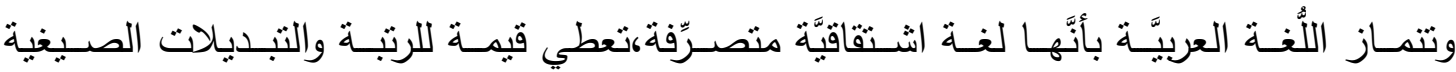
للكلمة،وهو أمر ذو (( جانب ديناميكيٌٌ مهٌٌُ له تأثثر في تطوّر المعجم،فكلّما دخلت كلمة جديدة للمعجم

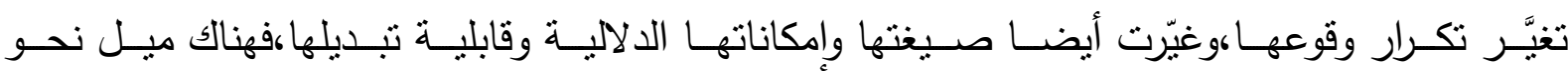
الاختصـار كوليس نحو الاتجاه الآخر .وهناك سمة أخرى للاقتصاد البنيويّ على المستوى المعجميّهوهي الميل إلى الصيخة غير القابلة للتغيّر للكلمةهوهو ما يرفع قابلية الكلمات للتبديل....وهذا الميل يعبّر عن

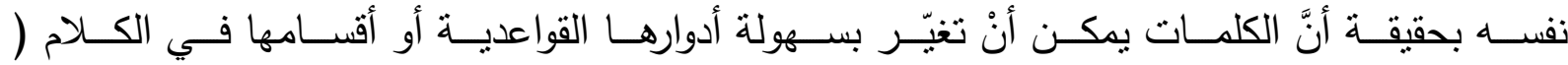

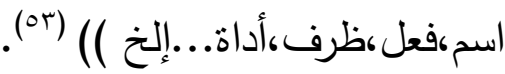
ومن أمتلنة التعدُّد الوظيفي للمبنى الواحدةقول صاحب العين: (( عَارَتِ العَيْنُ نَعَارُ عَوَارًا،وعَوِرَت

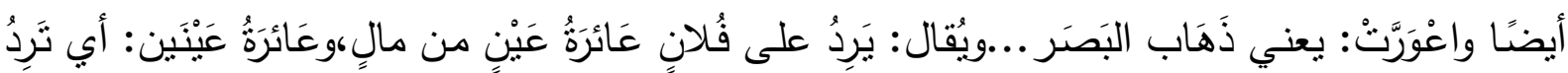

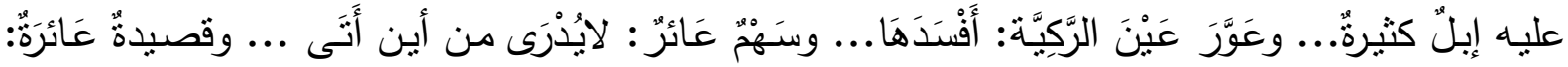

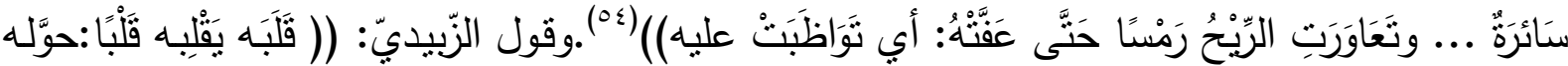

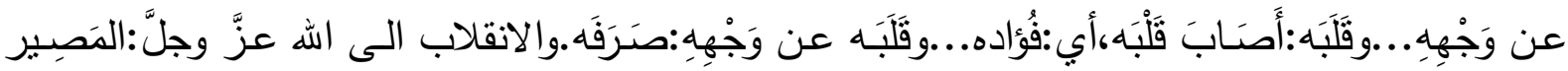

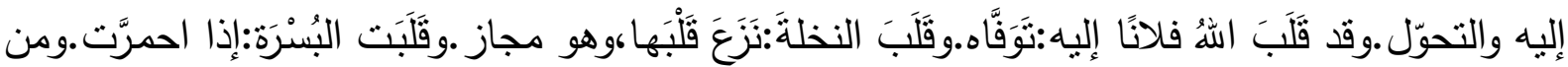

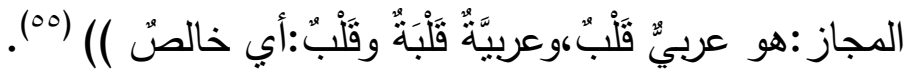
والناظر في ( عور) و ( قلب ) يجد لهما معاني مختلفة بـاختلاف ورودهما في السياق،وهذه

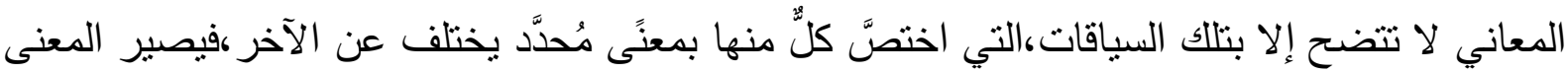
لدى القارئ مُحددًا ،ويعرف في أيّ حال يُسْنَعَل.إذ إنَّ البناء في هذه المعاني واحد ولكنَّ الاستعمال قد 


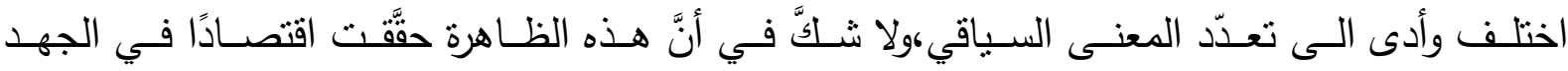
المبذول،ووفَّرت زخمًا دلاليّا بمبنى واحد وُظّف في سياقات متنوّعة.

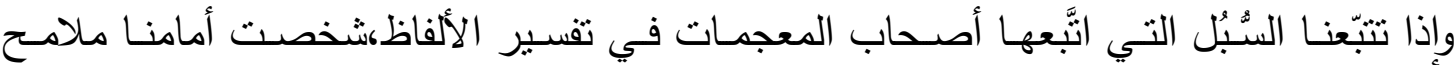
اقتصـاديَّة كثيرة،إِذ استعمل المعجميُّ أسلوب المغايرة في التفسير ،الذي يغني عن العبارات الطويلـة في

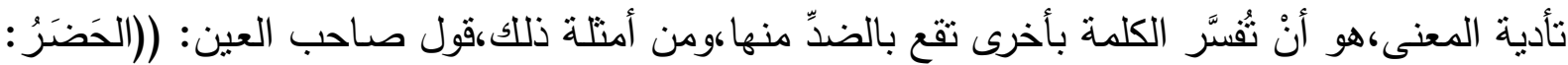

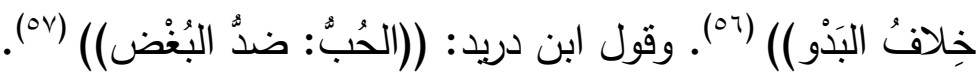
ويظهر الاقتصاد أيضـا في أسلوب المماثلة،وهو تقسير الكلمة بأخرى ممانلة لها في المعنى،أو

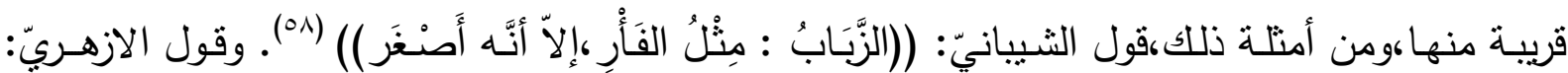

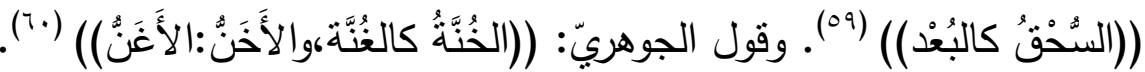
وتُشْتَعمل الممانلة كثيرًا في تفسير الألفاظ التي يُرَراد ضبطها،فيأتي المعجميُّ بلفظ مماثل للفظ المُراد تفسيره في الثكل والمعنى،فيكفيه اللفظ الضَّابط المفسِّر مؤونة التفسير بلفظ آخر .ولتوضيح ذلك نقرأ

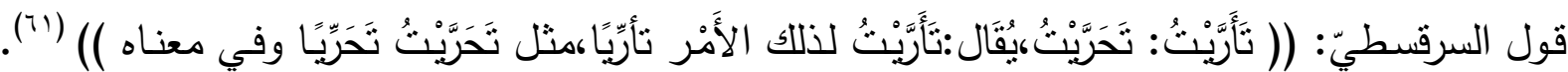

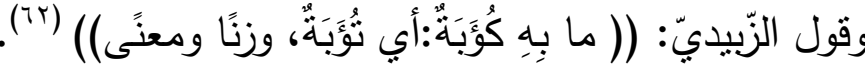

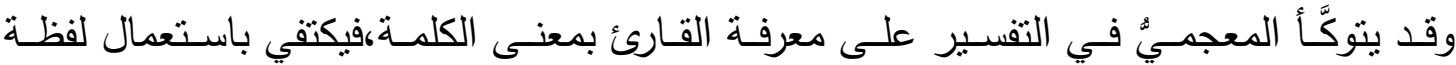

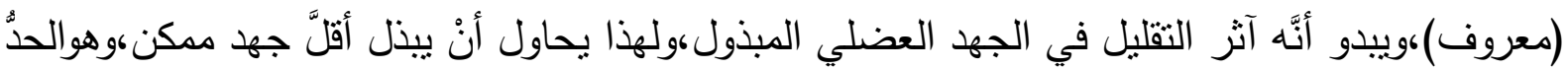
الأدنى من الكلام،من أجل الوصـول إلى أعلى معنى اعتمادًا على معرفة القارئ.فعندما يكون المعنى

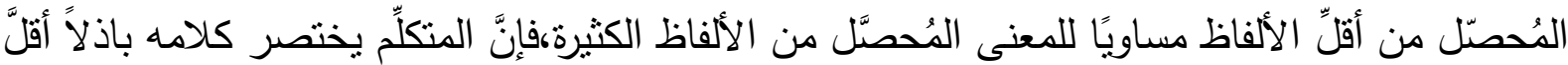

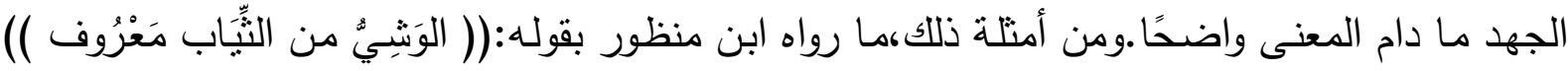

ومن ملامسح الاقتصـاد الأخرى اعتمـاد المعجميّ على الثـاهد اللغويّ في تفسير الكلمةهمن دون التعليق عليه،استتادًا إلى معرفة القارئ بمضمون هذا الثاهد،طلبًا للخفة وتقليل الجهد المبذول،ومن أمثلة ذللك،قول الصاحب بن عباد: (( وفي الحديث (نِكَاحُ الإمَاءِ خَيْرُ من الخَضْخَضَة، والخَضْخَضَنَة خيرُ من

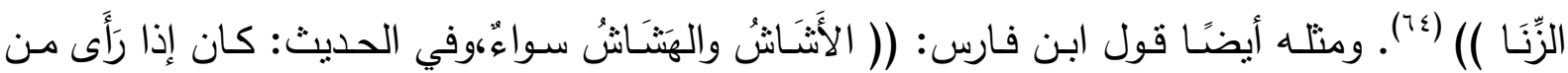

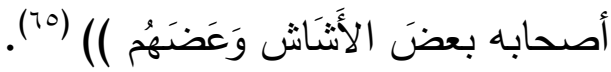
ومن السُّبُّ الأخرى التي توخَّى فيها المعجميٌُ الاقتصساد في الجهد المبذول،التقسير بالإحالة،وهو

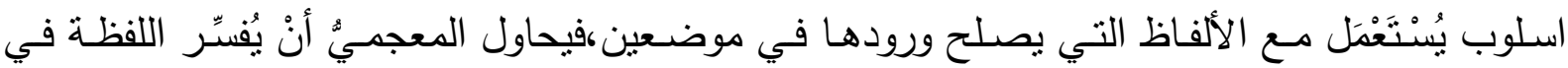
موضع واحد،ويُحيل في الآخر على ما قاله في الموضع الأول. ويشمل ذلك طائفتين من الألفاظ: 
ا احاهما: تلك التي اخْتُفِ في أصلهاهولاسيّما الألفاظ التي دخل في بنائها حرف علة،كقول ابن

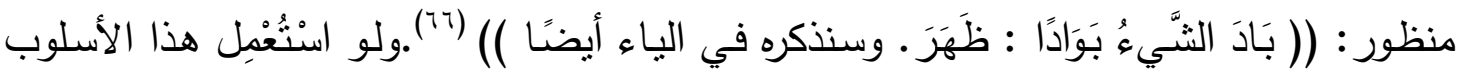

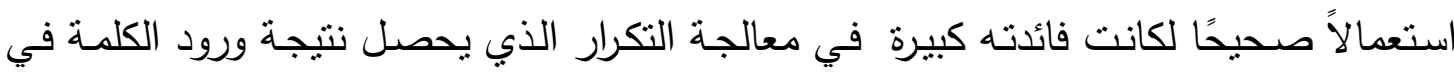
موضعين. وإخراهما: تلك التي تتشترك في التعليل الصرفيّ للصيغ،فيحاول المعجميٌ أنْ يبيّن ذلك في لفظة

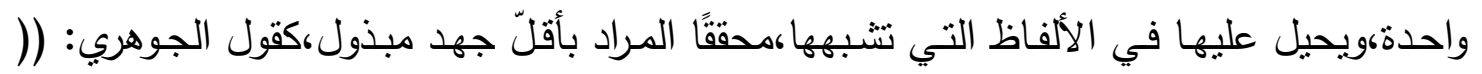

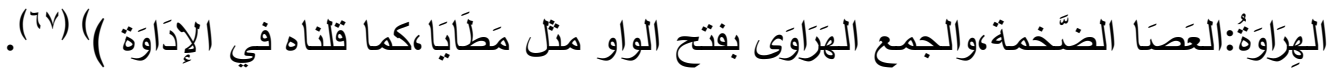

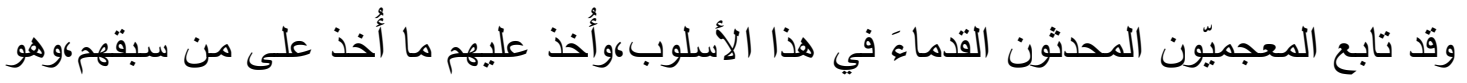

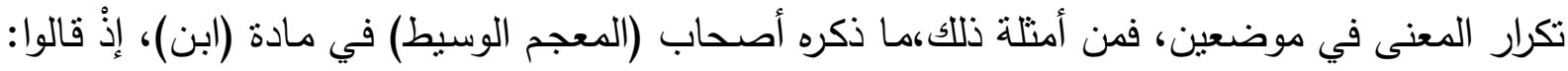

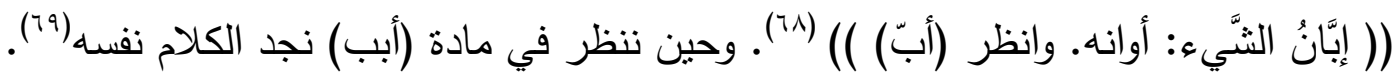

مخالفات اقتصاديَّة يقابل تلك المظـاهر الاقتصـادية في المعجم العربيّ مخالفات تبتعد عن الاقتصـاد في الجهد

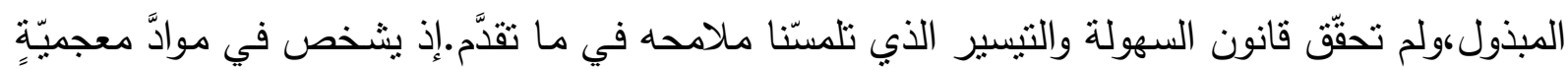
كثيرةٍ التكرار وإعادة المعنى الواحد بطرق مختلفة وبنصوص متعدودة ثُروى عن المتقدمين،وفي أحيان كثيرة

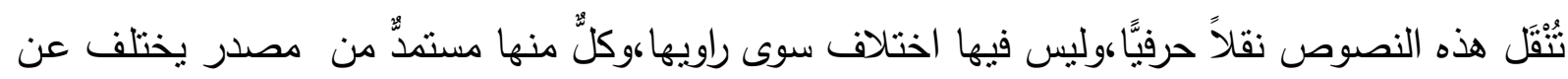

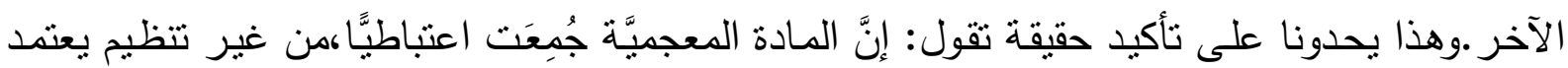

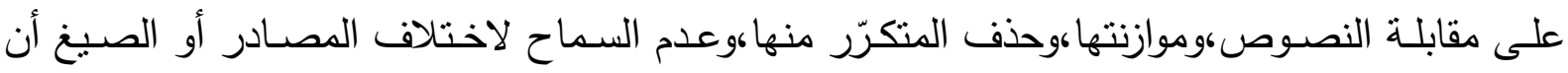

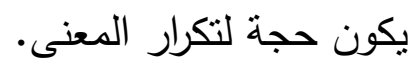
ومن أمتلـة تكرار المعنى بـاختلاف المصدادر،قول الأزهريّي: (( قال أبو عبيدة في قول النبيّ

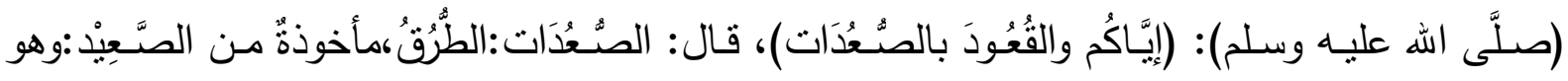

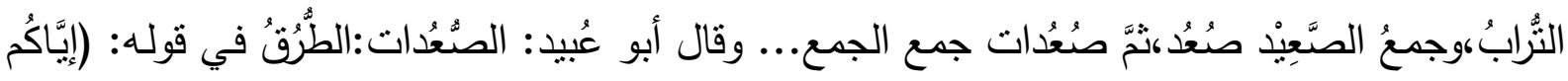

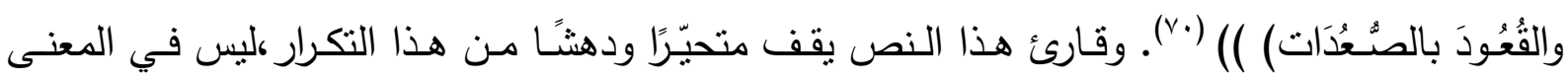

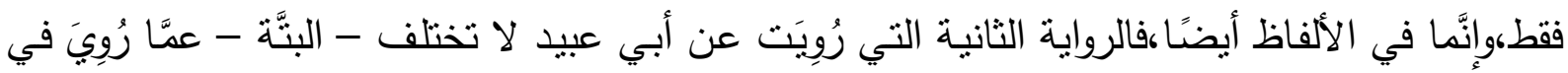
الأولى عن أبي عبيدة. وقد نسرَّب ذلك التكرار الى المعجمات الحديثة،الني حرص مؤلّفوها - بحسب دعواهم - على العى

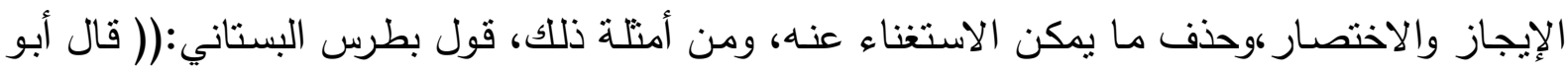

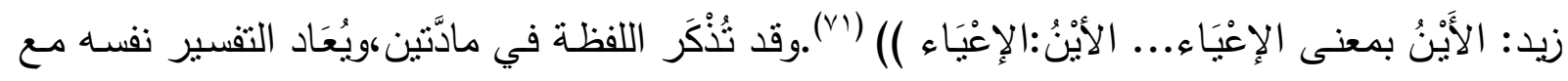




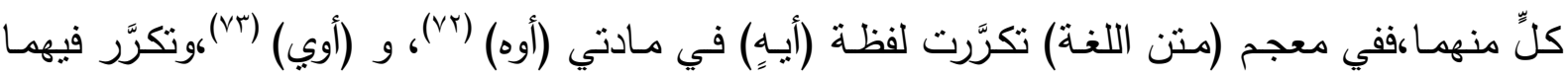
معناها.

ومن مظاهر التكرار الأخرى ما يسبّبه التفسير بالإحالة،إذ إنَّ المعجيّ يكرّر الكلام نفسه في كلا

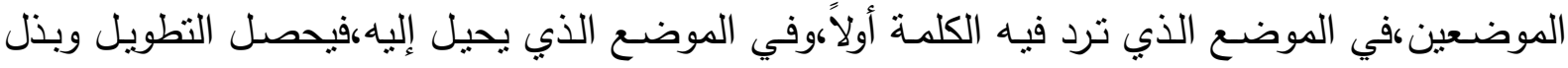

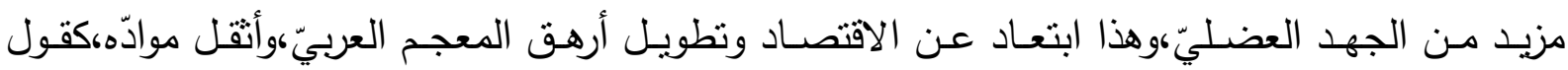

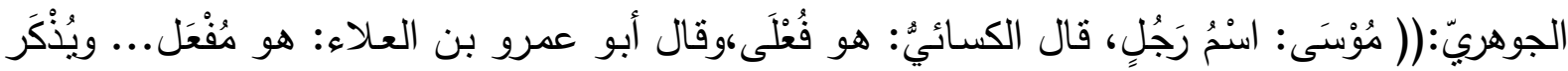

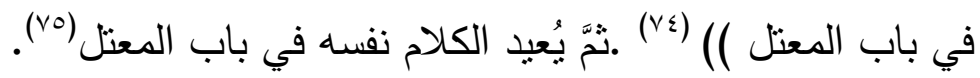

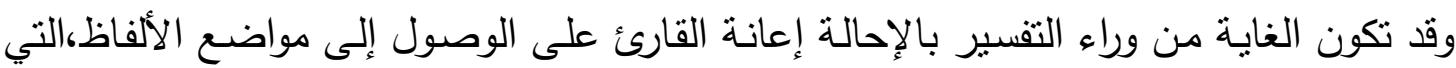

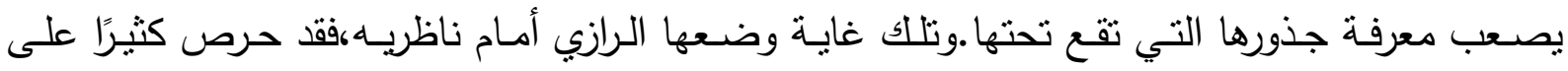

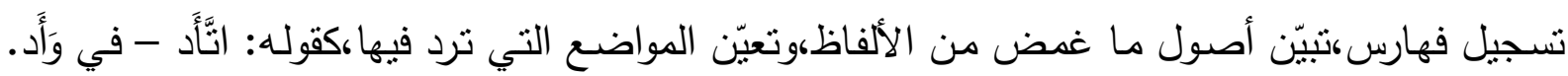

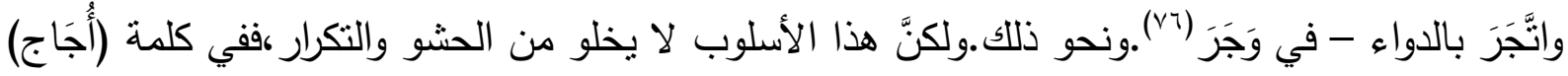

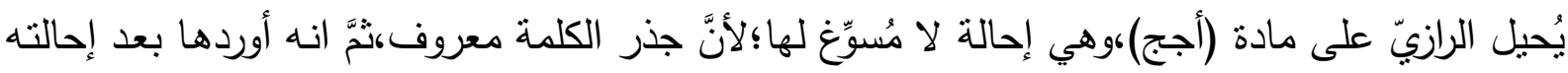
مباشرة:(VY).

وقد يكون التفسير بالسياق الاجتمـاعي سبيًا في الحشـو والتطويـل الذي عـانى منـه المعجم

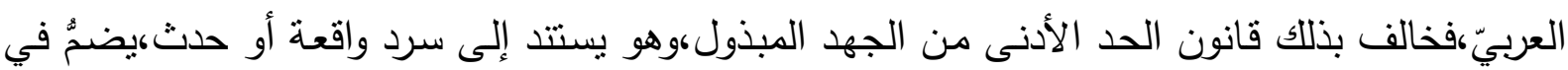
أثنائه الكلمة المُراد تفسيرها.وهو يوضتح المعنى الاجتماعي،الذي ثُدورولت به الكلمة في أدقّ ملامحها.

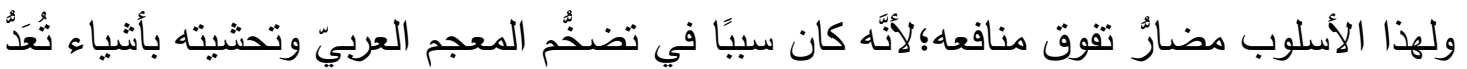

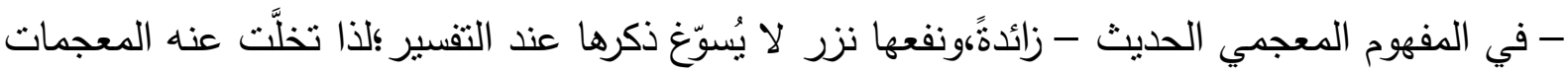

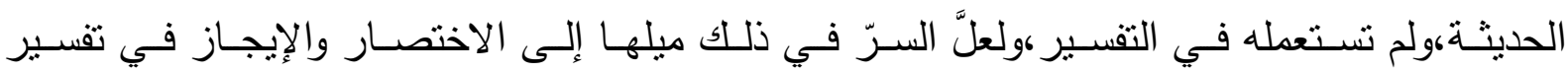
الكلمة،وإبقاء مـا ينفع لتوصيل المعنى لطالبه.وبذا سلمت مـن الإسـهاب والاستطراد الذي أنقل كاهل

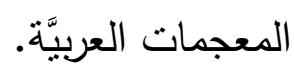
إنَّ حرص المعجميّ على الاقتصاد في الجهد المبذول قد أوقعه في الوهن والغموض،الذي لفَّ

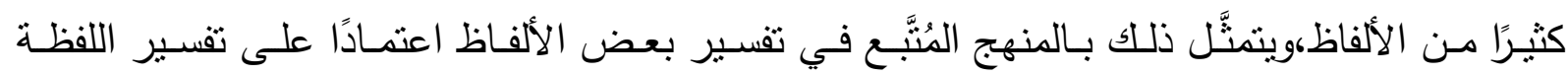

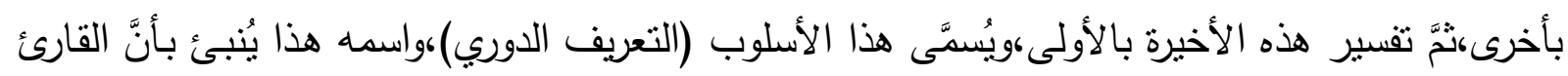

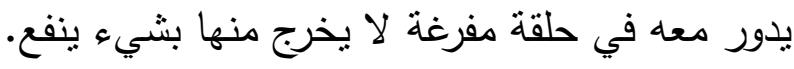

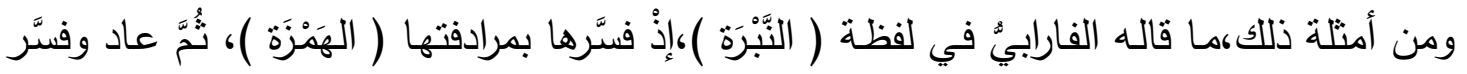

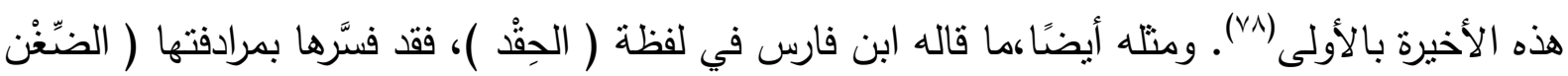
) (نثم عاد وفسَّر هذه الأخيرة بالأولى (va). 
ومن ملامـح التطويل والتكرار الذي ظهر في كثير من المواد عناية المعجميّين بضبط الألفاظ بالعبارة، وهو من السبل التي ظهرت ردًّا على ما اعتمد عليه المعجيُّون الأوائل من أساليب في الضبط ميط تؤدي الى التَّصحيف والتَّحريف،ولا سيَّما في الحروف المنتشابهة في الرسم.إذْ حرصوا على مراعاة ذلك في

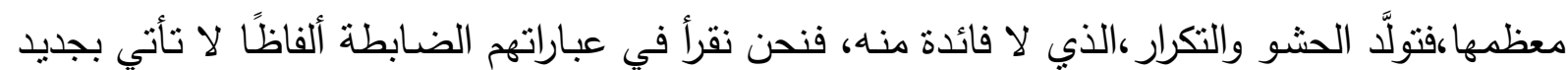

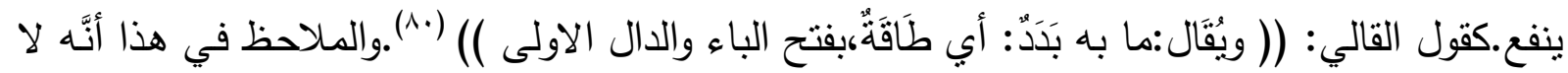
مسوِّ لتحديد حرف الدال بقوله (الاولى)؛لأنَّ الذهن لا ينصرف إلاّ لها،أمَّا الثانية فحرف إعراب لا يشمله الضبط.

أردنـا في هذا البحث أنْ نفتح البـاب على ظاهرة مهمـة تشخص في مواطن كثيرة من المعجم العربيّ،وهي ظاهرة الاقتصاد في الجهد المبذول،ولكنَّها قد تغيب في موادّ أخرى،ابتعد فيها المعجميٌٌ عن الاقتصاد ودخل في إطار الإفراط،الذي كان سبيًا رئيسًا في تضخٌّم المعجم واتساعه. وقد حاولنـا انتقاء مصـاديق هـذه الظـاهرة مـن المعجمـات العربيـة ابتـداء مـن العـين،ولم نغفل

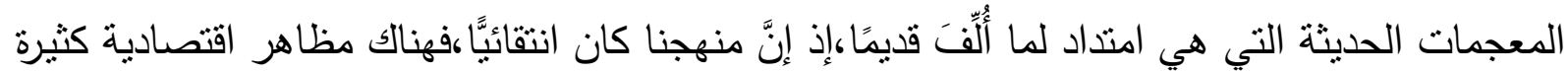
تعنُّ للباحث حين يداوم على القراءة في المعجم العربيّ،تجعلنا نقرٌ باطمئنان أنَّ هناك اقتصـادا في الجهد المبذول،ظهر على نطاق واسـع،وهذا لا يمنع من المخالفات التي حصلت هنا وهناك،ابتعد فيها صـانع المعجم عـن السـهولة والتيسـير الذي يثـير الى السـة الاقتصـادية التي ينبغـي أنْ تتوافر في المعجم

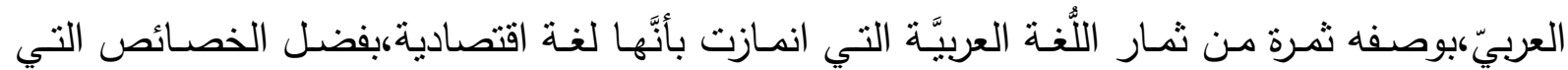
انفردت بها دون سائر اللغات.

ولم تكن الكتابـة في هذا الميدان الأولى،فقد سبقنا إلى البحث في الاقتصـاد اللغويّ باحثون،منهم الدكتور فخر الدين فباوة في كتابه (( الاقتصـاد اللغوي في صياغة المفرد ))،وقد جعله خاصنًا بصياغة المفرد.وقبله ظهر كتاب بعنوان (( الاقتصاد واللغة )) ألفه فلوريان كولماس،وترجمه إلى العربية الدكتور أحمد عوض،وهنالك رسالة ماجستير كتبتها ( وردة غديري ) بعنوان (( سمات الاقتصاد اللغوي في العربية - دراسة وصفية تحليلية ().

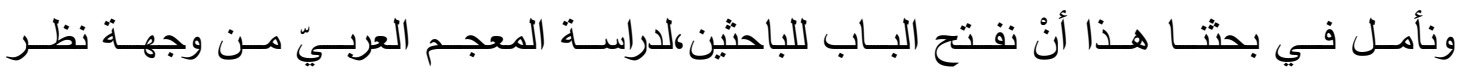
اقتصاديَّة،ووضع اليد على مظاهر هذه الظاهرة ومصاديقها،ومدى التزام المعجميّ بتطبيق مبدأ الاقتصاد في الجهد المبذول. 


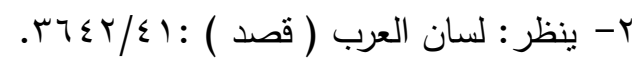

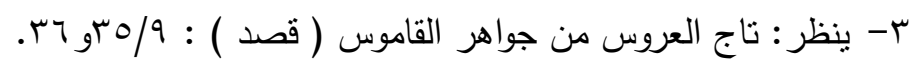

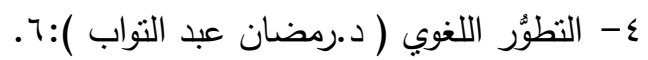

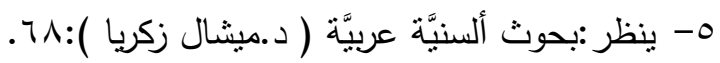

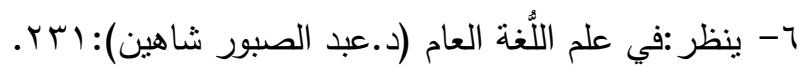

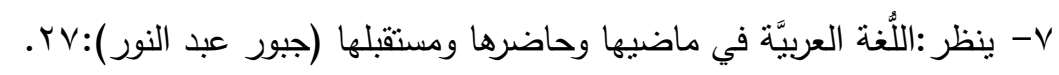

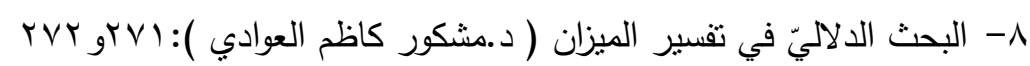
9- التاج ( قصد ):

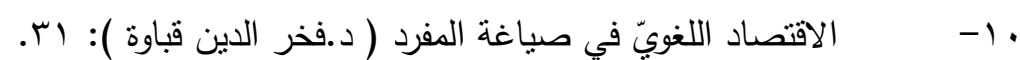
TV:

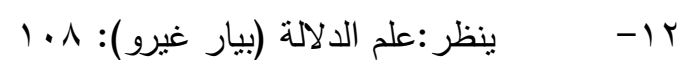

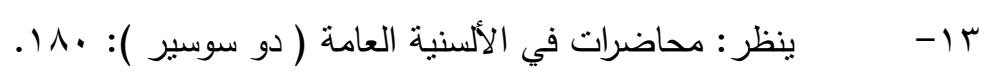

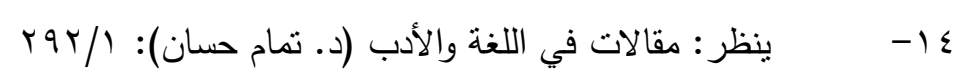

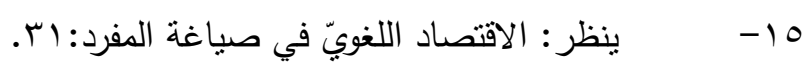

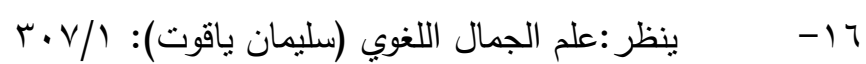

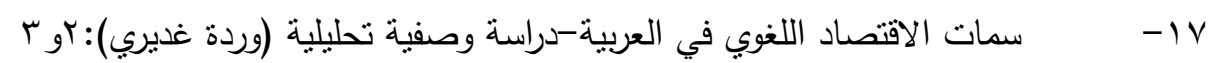

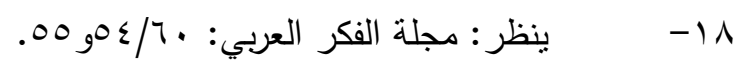

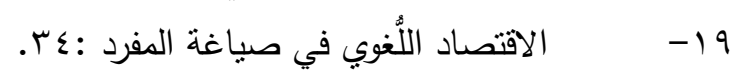

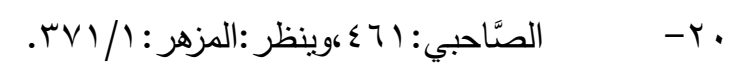

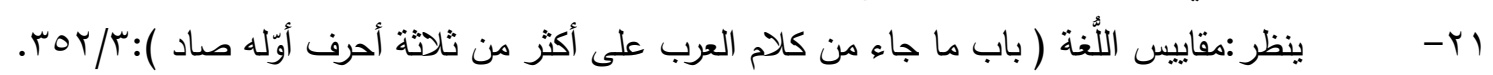

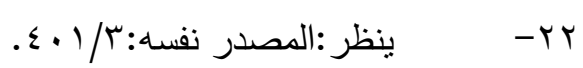

$$
\begin{aligned}
& \text { r } \\
& \text { ع }
\end{aligned}
$$

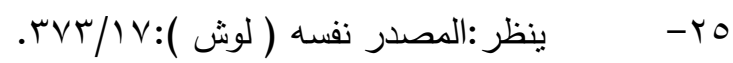

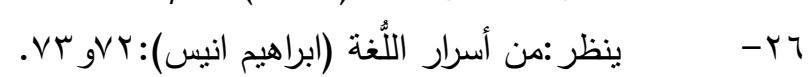

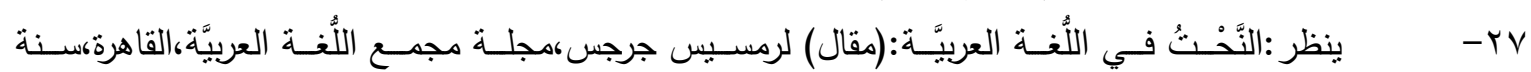

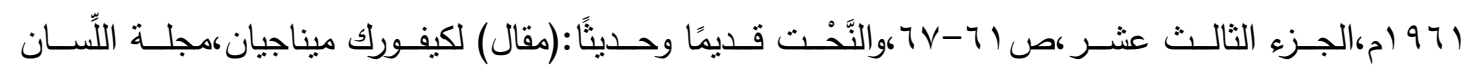

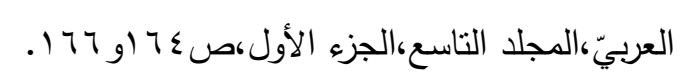

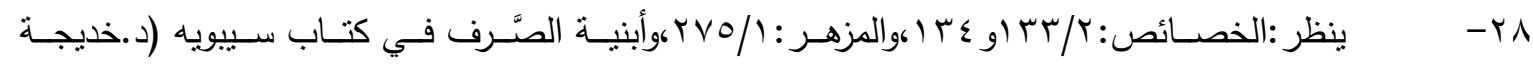

$$
\text { الحديثي): }
$$

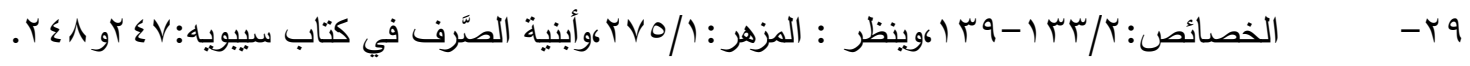




$$
\text { ا r }
$$

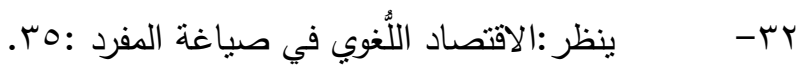

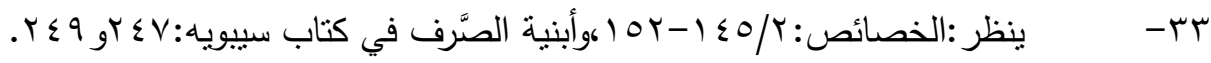

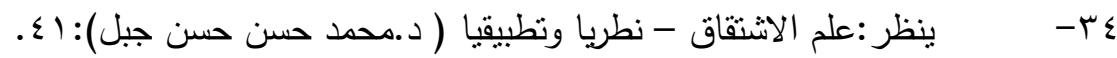

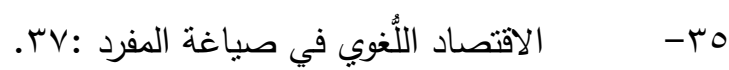

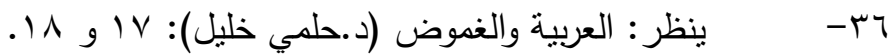

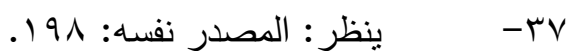

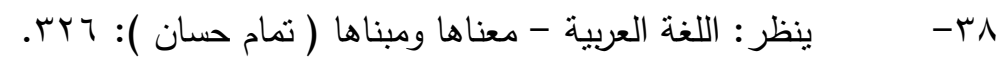

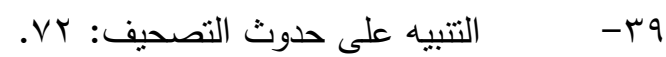

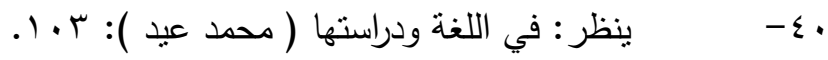

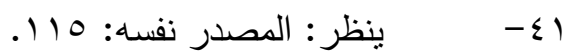

r

r

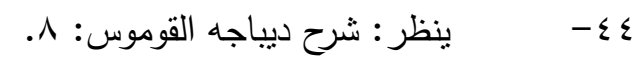

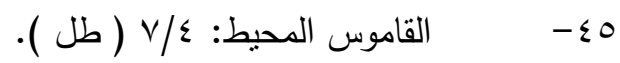

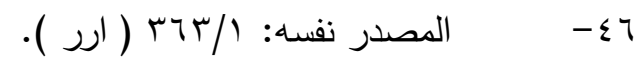

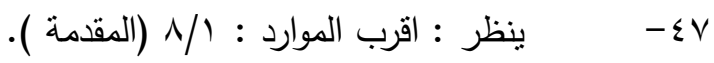

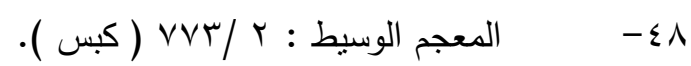

Q 9

o - -

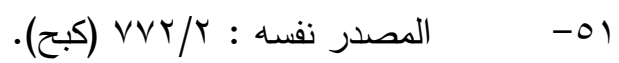

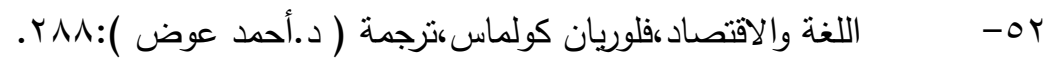

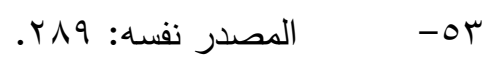

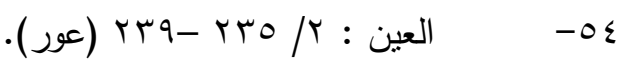

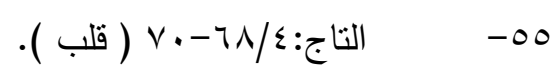

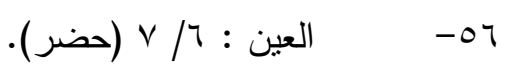

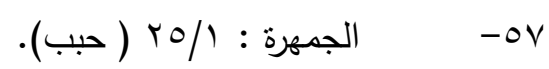

ا الجيم : - - -

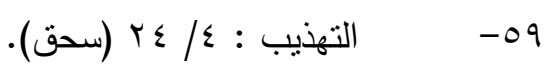

. - -

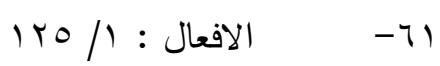

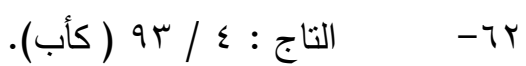

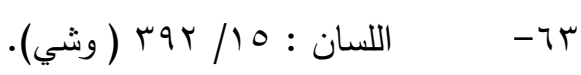




$$
\begin{aligned}
& \text { ع }
\end{aligned}
$$

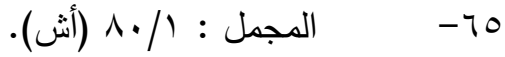

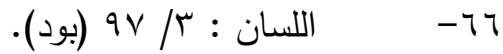

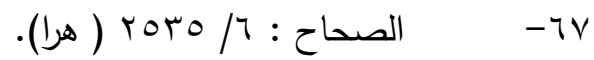

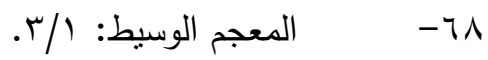

$$
\begin{aligned}
& \text { ال } \\
& \text { - } \quad-v \text {. }
\end{aligned}
$$

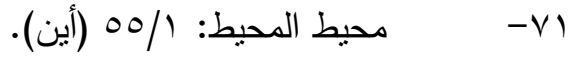

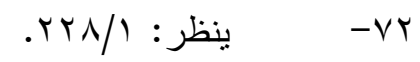

$$
\begin{aligned}
& \text { - } \\
& \text { ع }
\end{aligned}
$$

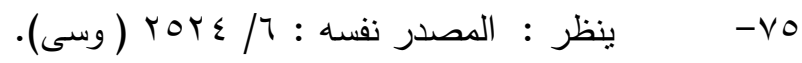

$$
\begin{aligned}
& \text { ينظر : مختار الصحاح : ع ع : }
\end{aligned}
$$

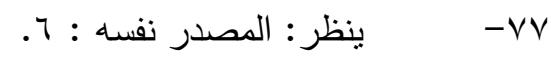

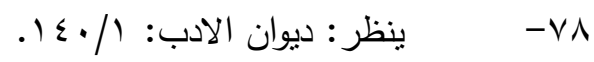

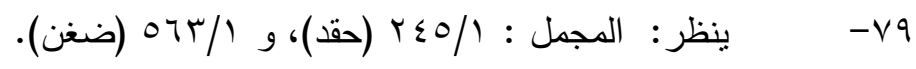

$$
\begin{aligned}
& \text {. }
\end{aligned}
$$$$
\text { المصادر والمراجع }
$$

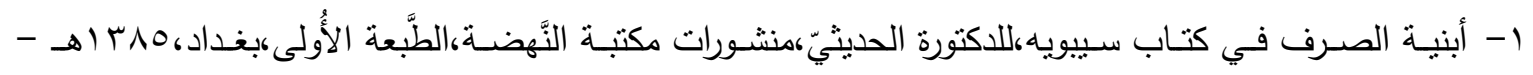

$$
\text { - } 970
$$

ץ- الأفعال، لابي عثمان سعيد بن محمد المعاقري السرقسطي (المتوفى في حدود . عهـ)،حقيق: الدكتور حسين

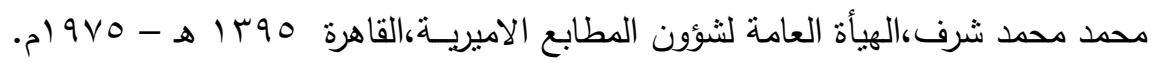

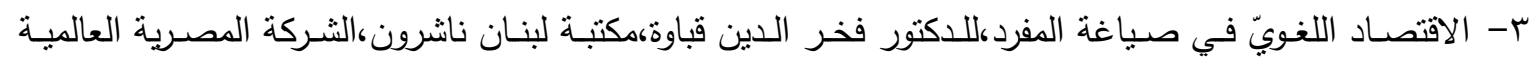

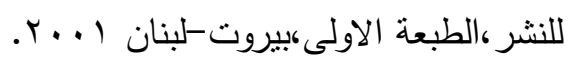

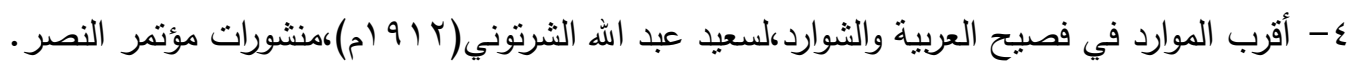

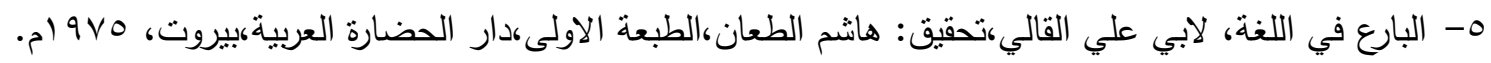

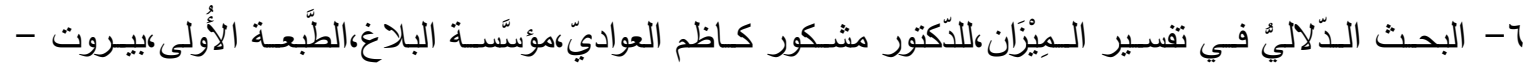

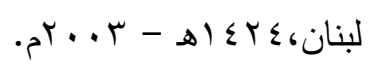

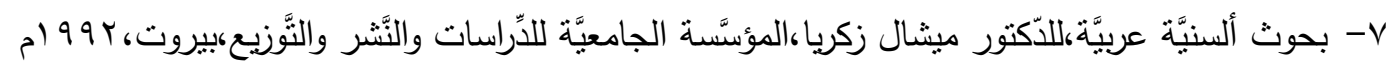

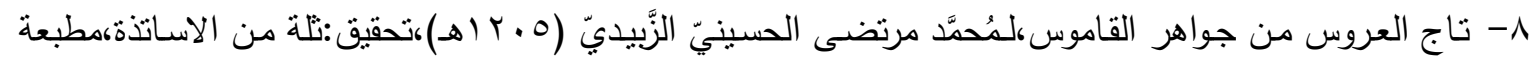
حكومة الكويت.

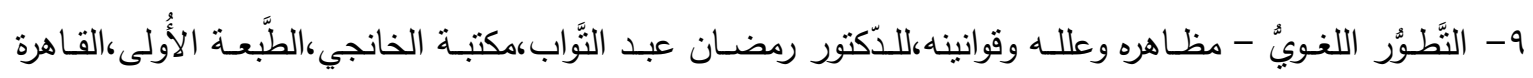

$$
\text { . }
$$


• 1- التتبيه على حدوث التصحيف،لحمزة بن الحسن الاصفهاني ( • بسهـ)،حقيق:الثيخ محمد حسن آل ياسين،الطبعة الاولى،مكتبة النهضة،بغداد،

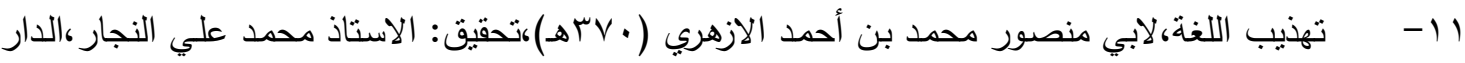
المصرية للتاليف والترجمة، د.ت.

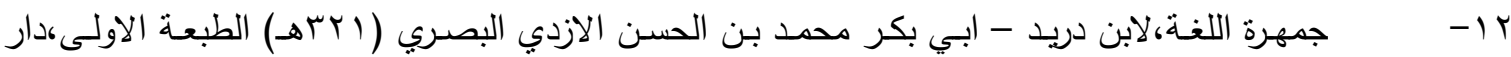

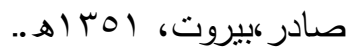

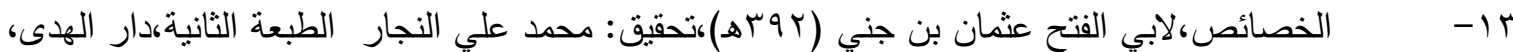

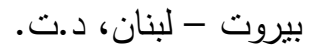

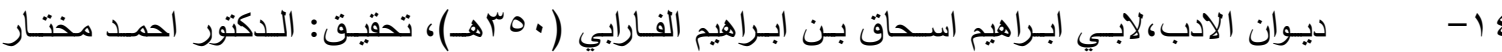

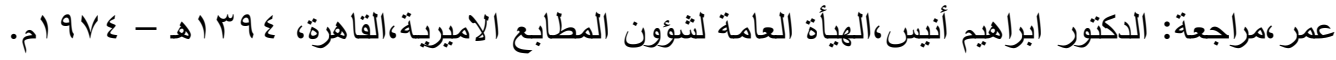
10- سمات الاقتصـاد اللغوي في العربيـة-دراسـة وصفية تحليليـة،لوردة غديري،رسـالة ماجستير ،الجمهورية

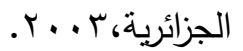

الصاحبي في فقه اللغة، لاببي الحسن أحمد بن فارس بن زكريا (90 (9ه)،تحقيق: أحمد صقر ،مطبعة

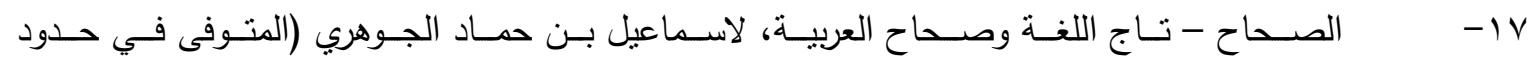

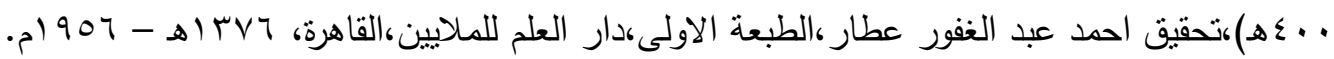

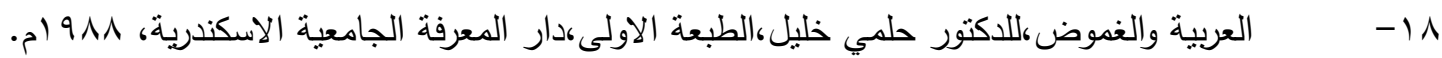

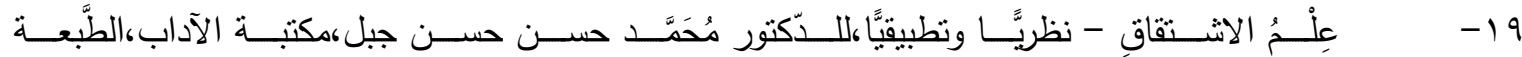

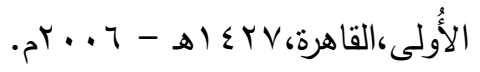

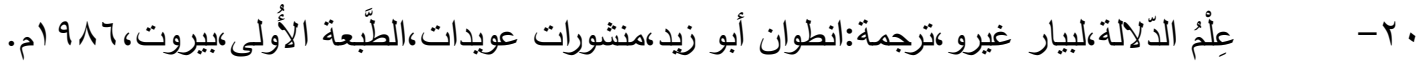

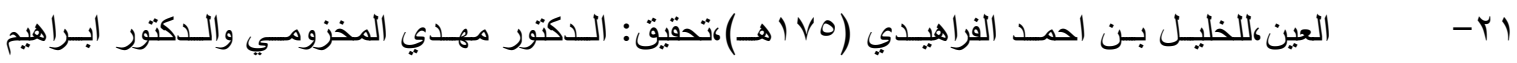

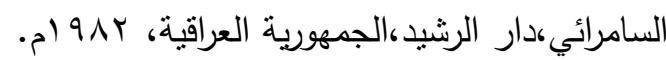

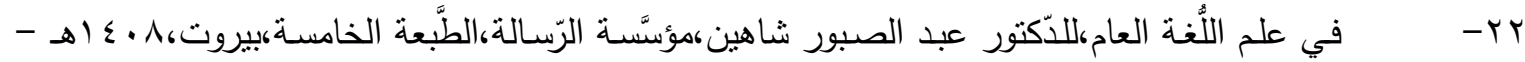
. ) $9 \wedge \wedge$

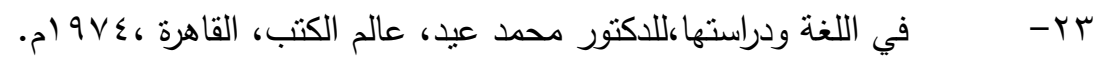

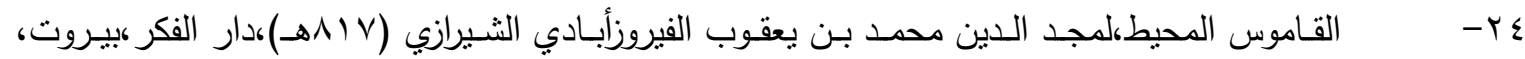

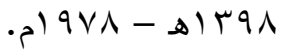

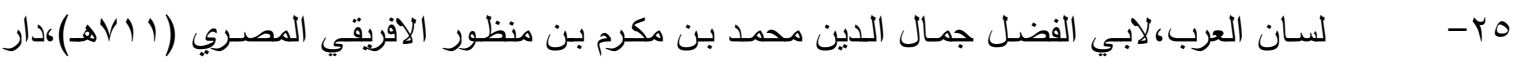

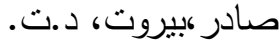

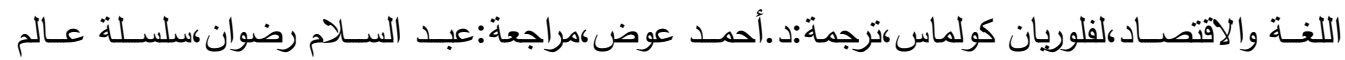
$-Y T$

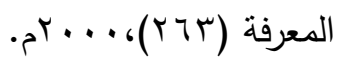

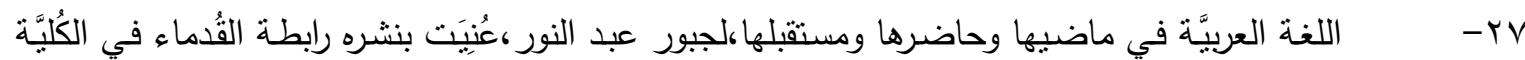
العلمانيَّة الفرنسيَّة في بيروت،د؟ 9 ام. 
اللغـة العربيـة- معناهـا ومبناها،للدكتور تمـام حسـان، الطبعـة الثانيـة، الهيأة المصرية العامـة للكتاب،

$-Y \wedge$ . $19 \vee 9$

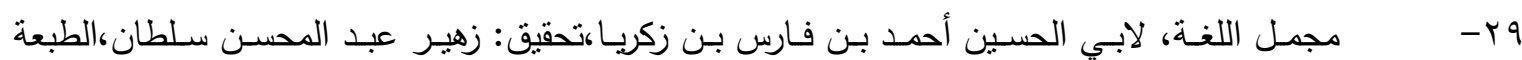

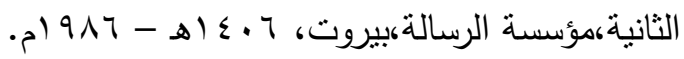

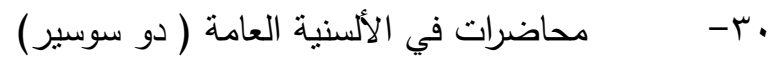

المحيط في اللغة،للصاحب اسماعيل بن عباد (10ـهـ)تحقيق: الثيخ محمد حسن آل ياسين،الطبعة

$-r$

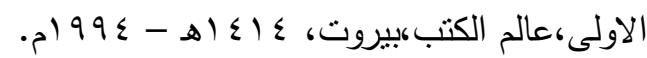

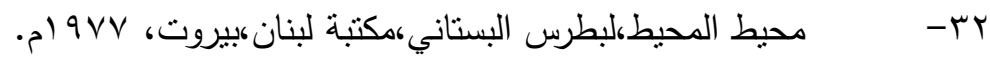

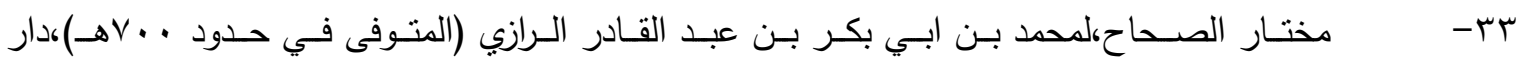

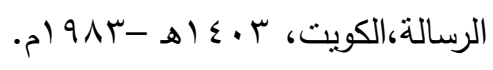

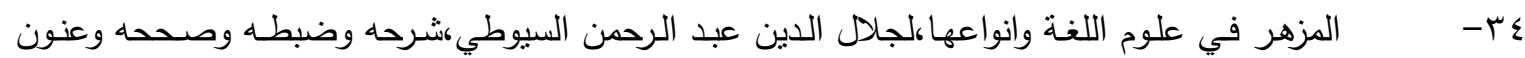

موضـوعاته وعلق حواثشبه: محمد احمد جاد المولى وآخرون دار إحباء الكتب العربية،عيسى البابي الحلبي

$$
\text { وشركاه، د.ت. موشوعانه }
$$

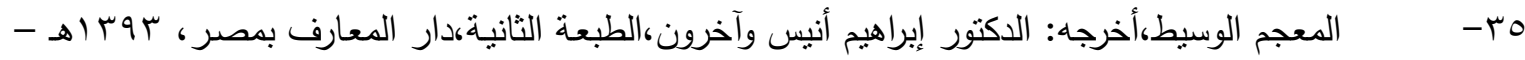
.

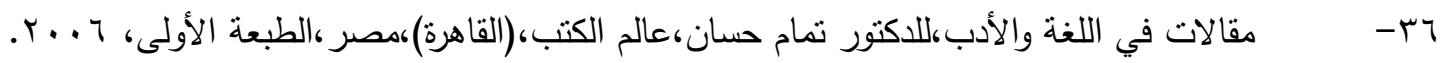

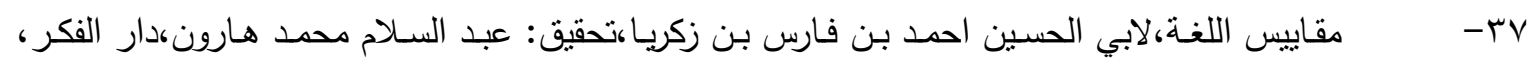

$$
\text { . } 19 \vee 9-81499
$$

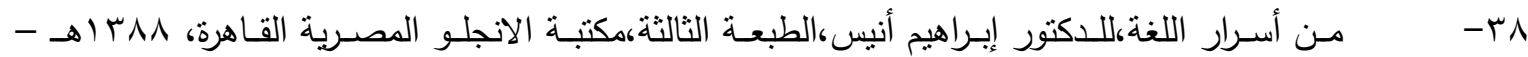
.01971

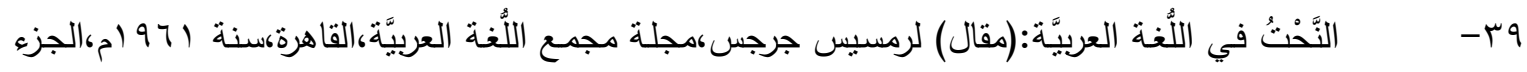
الثالث عشر . • ع - النَّحْت قديمًا وحديثًا:(مقال) لكيفورك ميناجيانهمجلة اللّّان العربيّ،المجلد التاسع،الجزء الأول. 